TORRES MANRIQUE, J.I.., «Temeridad y malicia procesales al banquillo: crónica de dos lacras jurídicas que pretenden consolidarse», REDUR 9, diciembre 20II, págs. 375-402. ISSN I695-078X

\title{
TEMERIDAD Y MALICIA PROCESALES AL BANQUILLO: CRÓNICA DE DOS LACRAS JURÍDICAS QUE PRETENDEN CONSOLIDARSE
}

\author{
Jorge Isaac TORRES MANRIQUE
}

ABOGADO

CONSUltor de la Oficina Defensorial Lima Este (Perú)

SuMARIO: I. Introducción. II. Acerca de la temeridad procesal. III. Sobre la malicia procesal. IV. Litigante temerario. V. El artículo II2 («no deslindado») del Código Procesal Civil peruano. VI. Temeridad y malicia vs. principios procesales. VII. Temeridad y malicia procesales en la literatura. VIII. Teoría del abuso del derecho. VIII.I. Definición. VIII.2. Naturaleza jurídica. VIII.3. Origen y evolución. VIII.4. Sujetos que incurren en abuso de derecho. VIII.5. Formas para determinar dicho abuso. VIII.6. Efectos del abuso de derecho. IX. Costas, costos, multas, responsabilidades y sanciones. IX.I. Costas. IX.2. Costos. IX.3. Multa. IX.4. Responsabilidades. IX.5. Sanciones. X. Normatividad aplicable al derecho peruano. XI. Legislación extranjera. XII. Criterio del Tribunal Constitucional peruano. XIII. Reflexiones finales. XIV. Sugerencias. XV. Propuesta legislativa.

RESUMEN: Existen graves y anómalos comportamientos del día a día abogadil, con el único fin de perjudicar a la contraparte o a terceros, se presentan con gran frecuencia en el proceso, obstruyendo la impartición de justicia; es así que el autor aborda en el presente trabajo los temas de la temeridad y malicia (que son absolutamente contrarios a la justicia y al derecho) en el proceso civil desde amplias perspectivas doctrinales, legislativas y jurisprudenciales, analizando sus orígenes, identificando y distinguiendo ambas figuras y desarrollando con rigor académico, su problemática en la actualidad; desentrañando las causas de su comisión y sugiriendo derroteros como pautas para su aminoramiento.

PALABRAS ClAVE: temeridad procesal, malicia procesal, debido proceso, corrupción, dilación, infiel cumplimento.

\section{RECKLESSNESS AND MALICE PROCESS TO BENCH: CHRONICLE OF TWO LEGAL ILLS THAT AIMS TO CONSOLIDATE}

ABSTRACT: It exist serious and anomalous behaviours of the daily life of a lawyer, with the only end of harming to the tally or third, they are presented with great frequency in the process, obstructing the impartation of justice; the author it approaches work presently the topics of the recklessness and malice (that are absolutely contrary to the justice and to the right) in the civil process from wide doctrinal, legislative perspectives and jurisprudential, analyzing their origins, identifying and distinguishing both figures and developing with academic rigor, their problem at the present time; figuring out the causes of their commission and suggesting courses like rules for their decrease.

KEYWORDS: procedural recklessness, procedural malice, process correctly, judicial proceeding, corrupt practices, delay, unfaithful observance. 


\section{Introducción}

En principio, tenemos que los efectos de la temeridad y malicia (mala fe) procesales generan que el derecho (y el proceso) se distorsionen, de emblemáticos a paradójicos, lo cual preocupa sobremanera ya que Fernando De Trazegnies, citado por Valdivia Cano, señala: «en la Europa del siglo XI, las primeras Universidades se fundan para enseñar Derecho. Y, evidentemente, esto no es una casualidad, no es un azar cultural: las Universidades nacen con miras al Derecho, porque a su vez el Derecho era visto entonces como un modelo de pensamiento riguroso... los estudiantes no acudían a formarse como juristas, sino como hombres; o quizá, creían que formándose como juristas eran hombres mas completos(...)» (Valdivia Cano I998).

En ese sentido, es preocupante el cambio de rumbo o dirección -en sentido contrario, diríamos: de la corrección a la incorrección- del sentido de la profesión de abogado, es decir, que mientras en sus inicios era ciertamente auspicioso, con el transcurso del tiempo se deformó o se inclinó a favor (aunque no mayoritariamente, pero cada vez en aumento) de la temeridad y malicia (mala fe) procesales. Sobre todo cuando de la denominación misma del área de estudio, conocimiento o saber del abogado $\left(\right.$ derecho $\left.^{\mathrm{T}}\right)$ se puede desentrañar sus significados o acepciones básicas (recto, correcto), que aluden a lo sensato, justo, razonable, honesto, legal, lícito, procedente; que debe lógicamente caracterizar a la quintaesencia de la abogacía, como lo fue en sus inicios y debe continuar siéndolo.

Pero, es más preocupante aún si tomamos en cuenta que el proceso se ve desnaturalizado por el litigio malicioso o abuso del derecho de litigar (así, con mucha razón es harto sabido -en el Orbe- que comúnmente en el proceso aflora y se desenvuelve campante lo mas oscuro y retorcido de la miseria humana). Más aún cuando los que violentan o violan el proceso reclaman que sus argucias ilegítimas sean accedidas en nombre de la vigencia y defensa misma del debido proceso. Así, el juez de la causa, en el ejercicio de su función de administrador y justicia y defensor de la corrección del proceso, no puede permitir que las partes, por cualquier medio o modo, festinen el proceso; dicho en otros términos, el magistrado es y tiene que comportarse como garante del fiel cumplimiento del debido proceso en el juicio.

Además, las partes y los abogados deben tomar en cuenta que al hacer fraude, estafa o incorrección en el proceso, o accionar con temeridad procesal, no solo incurren en abuso del derecho, sino que también vulneran las atribuciones y majestad del juez, los derechos de la parte contraria, y también, por si fuese poco, el debido proceso.

La actuación procesal racional colabora facilitando la finalidad buscada por el accionante. Una actuación procesal irracional minimiza o lo conculca, perjudica o destruye. Se debe combatir, la irracionalidad procesal usada tanto para dilatar el proceso, como también para evitar la imposición de una sanción. El litigante que varía o frustra el fin del ordenamiento procesal acciona desviadamente; genera la desnaturalización del mismo, además de incurrir en inconstitucionalidad e irrazonalibilidad. En ese sentido: «toda irrazonabilidad es inconstitucional [...] la regla de razonabilidad marca un límite más allá del cual, la irrazonabilidad implica una violación a la Constitución» (Bidart Campos i968, 238).

\section{Acerca de la temeridad procesal}

La temeridad procesal «consiste en la conducta de quien deduce pretensiones o defensas cuya inadmisibilidad o falta de fundamento no puede ignorar con arreglo a una mínima pauta de

\footnotetext{
${ }^{\text {I }}$ En inglés: law, right. Francés: droit. Alemán: gerade, Rect. Portugués: directo. Italiano: dititto, etc.
} 
razonabilidad, configurándose, por lo tanto, frente a la conciencia de la propia sin razón». (Palacio, L. E. y Alvarado Velloso I992, 393).

La temeridad no es otra cosa que una acción, en este caso actuar procesal, que desborda lo normal, lo razonable y lo debido, así como ataca valores morales del demandado quién se ve obligado a defenderse, si es que lo puede hacer sobre afirmaciones tendenciosas. Sin embargo, quien acciona defendiéndose, aunque sea claro conocedor de su culpabilidad, no puede ser calificado de temerario, ya que es lícita la búsqueda de un resultado atenuado o -por lo menosen previsión de no ser víctima de un abuso de derecho.

Litigar con temeridad o accionar con temeridad en el juicio es la defensa sin fundamento jurídico. Es la conducta de quien sabe o debe saber que carece de razón y/o falta de motivos para deducir o resistir la pretensión y, no obstante ello, así lo hace, abusando de la jurisdicción, o resiste la pretensión del contrario.

La conciencia de no tener razón o el saberse actuando sin poseer de razón legal, es lo que condiciona la temeridad. El comportamiento de temeridad se refleja ante el magistrado, a través de toda la actuación en el proceso por lo absurdo, caprichoso, etcétera, de las pretensiones o defensas ${ }^{2}$.

Por otro lado, recurrir al tedio, aburrimiento y en consecuencia extender o prolongar el tiempo del proceso alegando un sin fin de coartadas, ya sea enfermedad o viaje, con la finalidad de acrecentar la cantidad de los honorarios y, lo que es peor, muchas veces en casos donde se sabe a ciencia cierta que no se podrá ganar; son claros ejemplos del actuar temerario a nivel procesal. La declaración del Decano del Colegio de Abogados de Lima, Walter Gutiérrez, es muy clara y evidente, al señalar que: «El 60\% de los expedientes que existen en los órganos jurisdiccionales corresponde a procesos chatarras, frívolos, que no tienen fundamento legal o fáctico, pero que son presentados impunemente por abogados inescrupulosos, sobrecargando el sistema y volviéndolo más ineficiente».

La temeridad no es de reciente data, ya que en el derecho romano la parte vencida era condenada al pago de las costas de la contraria, tomándose como base la idea de la temeridad en el proceso. Luego, se introdujo el principio del vencimiento como justificativo del pago total de las costas. En ese sentido, tenemos que Piero Calamandrei, en su publicación «Elogio de los jueces escrito por un abogado», señala en lo referido a ciertas relaciones entre los abogados y la verdad, así como analiza la obligada parcialidad del defensor, en ese sentido refiere: «El abogado, como el historiador, traicionaría su oficio si alterase la verdad relatando hechos inventados (...)» (Torres Manrique 2008).

Vemos imprescindible definir los términos «temerario y temeridad» (Cabanellas, I994); en ese sentido tenemos que: i) El primero significa: «imprudente; quien desafía los peligros. Pensamiento dicho o hecho sin justicia ni razón; y en especial cuando ataca valores morales del prójimo»; ii) El segundo, constituye una: «acción arriesgada, a la que no precede un examen meditado sobre los peligros que puede acarrear o los medios de sortearlos. Juicio temerario, el formulado sin la debida razón y fundamento. En lo psicológico y en la resultante vital, la temeridad, alineada en cierto grado en la actitud suicida, cuando el desafío entraña contingencias considerables para la existencia o la integridad física, encuentra móviles desde el interés más egoísta al sacrificio más excelso; ya que corresponde a actuaciones que se escalonan desde la agresión y el despojo delictivo al salvamento del prójimo y a intentos heroicos. En la esfera jurídica concreta, el litigar con temeridad, sin probabilidad al menos de que la causa pueda

\footnotetext{
${ }^{2}$ En ese sentido, consideramos necesario dejar constancia que el solo hecho de encontrarse en ausencia de razón no significa que se esté en situación de temeridad, pues de ser así todo litigante perdedor de una causa sería pasible de sanción; no lo es tampoco el error, ni la ausencia o pobreza de fundamentación de las pretensiones; ni la negligencia; mucho menos la existencia de jurisprudencia obligatoria contraria a la pretensión invocada.
} 
triunfar por hechos favorables o argumentos aún débiles que alegar, lleva consigo la condena en costas. En los ordenamientos procesales donde tal medida no se funda, cual exige la responsabilidad civil, el hecho del vencimiento; sin excluir un posible recargo, ya punitivo, por movilizar de mala fe a la justicia».

Debemos tener presente que el magistrado, en lo referido a la temeridad procesal, es responsable de supervigilar el proceso desde dos perspectivas: i) desde el litigio o tema de fondo y ii) desde el actuar o comportamiento de las partes. Así lo señaló Eduardo Couture en el Proyecto del Código de Procedimiento Civil uruguayo: «...ningún campo es más apropiado que el del proceso para poder efectuar una vigilancia directa sobre la buena fe. Allí está el magistrado que es, simultáneamente, juez del conflicto y juez del proceso. Él discierne, dentro del ámbito del mismo juicio, no solo quien tiene razón, sino también como se han comportado los que pretenden tener razón...».

\section{Sobre la malicia procesal}

Además, es importante precisar o tener en claro los significados de temeridad y malicia. Así, tenemos que: i) «La primera, consiste en la conducta de quien sabe o debe saber su mínima razón para litigar y, no obstante, lo hace, abusando de la jurisdicción; y ii) La segunda, se configura en cambio, por el empleo arbitrario del proceso o actos procesales, en contraposición a los fines de la jurisdicción, con un objeto netamente obstruccionista. Abusa y agrede a la jurisdicción» (Maurino 200I).

Malicia procesal es la utilización arbitraria de los actos procesales en su conjunto (inconducta procesal genérica) o aisladamente cuando el cuerpo legal los conmina con una sanción específica (inconducta procesal específica), y el empleo de las facultades, que la ley otorga a las partes, en contraposición con los fines del proceso, obstruyendo su curso y en violación de los deberes de lealtad, probidad y buena fe (Gozaíni i988). Malicia es, por ejemplo, confabular con el notificador para que notifique en un domicilio diferente del que consta en la cédula, con el oscuro propósito de que el demandado o notificado pierda sus derechos por la no comparecencia en término al proceso.

La temeridad se evidencia en tanto se vincula con el actuar o proceder procesal de fondo y la malicia se identifica más bien con la forma valiéndose de lo que está regulado, abusando de ello. Sin embargo, no debemos perder de vista que tanto la temeridad como la malicia -mala fe(demostrados) en que incurre el litigante deben ser sumaria y ejemplarmente sancionadas por el juez del proceso.

El legislador peruano no hace referencia expresa al término «malicia procesal» $o$ «malicia» (solo menciona «mala fe»), sin embargo, sí lo hace de manera implícita, dado que, por ejemplo, el inc. 6 del art. II2 del Código Civil peruano advierte: «Se considera que ha existido temeridad o mala fe... cuando por cualquier medio se entorpezca reiteradamente el desarrollo normal del proceso». Ergo, la malicia, además de entorpecer, requiere ser «reiterada». Al respecto, consideramos que dicho deslinde y precisión son imprescindibles y urgentes de realizarse, así como mostramos nuestro desacuerdo con la exigencia de la reiterancia referida para el caso de la mala fe o malicia procesal. Sin embargo, dichas disquisiciones desarrollamos en el epígrafe V «El artículo iı2 ('no deslindado') del Código Procesal Civil peruano»-, así como en las reflexiones finales y sugerencias, respectivamente.

Finalmente, hablando en términos «jurídico deportivos», diríamos que la temeridad y malicia (mala fe) procesales son opuestas o antagónicas al fair play («realización de la actividad deportiva de forma digna sin perjudicar o dañar intereses ajenos, actuando con la mayor rectitud y probidad, con un comportamiento adecuado y esperado; bajo estos lineamientos el deporte debe 
ser realizado honradamente, sin dañar a la otra parte, presupone justicia, igualdad, lealtad, honestidad, aceptación y respeto al adversario y por las diferencias de cada uno, entre otros valores morales», Varsi 2006); consecuentemente reiteramos que la malicia o mala fe procesal, es en cierta forma, la negación o violación del fair play aplicado a lo jurídico.

\section{Litigante temerario}

La aparición del término temerario procesal o litigante temerario se produce en los inicios de la culpa aquiliana o extracontractual de la ley del mismo nombre, siendo las costas una forma de pena civil contra quien sin razón alguna ejercitaba una acción o temerariamente se oponía a ella, generándose un daño evidentemente injusto que debía ser definitivamente reparado.

El litigante temerario, denominado por Justiniano «improbus litigatur» (contendiente deshonesto, pleitista de mala fe), tiene una naturaleza binomial o bifronte, es decir: i) demanda o se excepciona a sabiendas de su falta de razón o sin motivo valedero, ejerciendo una litigación bizantina, ii) activando la prestación de la función jurisdiccional basándose en motivos fútiles, lo que constituye una actualización del supuesto de falta de lealtad o de probidad procesal.

Improbus deviene de improbe e improbe significa con maldad o perversamente, de modo defectuoso, injusto e irrazonado. Es quién activamente tiende trampas y/o estafas procesales con una subjetividad dolosa, con la finalidad de engañar al juez y derrotar y/o dañar o perjudicar a la parte contraria, recurriendo al uso de medios ilegales y falsos para obtener el resultado propuesto.

Litigar temerariamente, es actuar de mala fe, con la idea de lograr beneficios en base a mentiras, engaños, ocultar información, etc. Así también, quien inicia una demanda, o interpone una excepción sabiendo que no tiene un mínimo de razón, incurre en temeridad litigante. Por otro lado, consideramos que proceder maliciosamente en una suerte de ¡Error! Referencia de hipervínculo no válida.confabulación abogadil consistente en burlar al magistrado con el propósito de conseguir un beneficio (que no le corresponde legalmente) en la causa y en perjuicio también del patrocinado, muchas veces no solo para ocultar sus errores de patrocinio, sino también para incrementar sus honorarios de manera ilegal prolongando (el demandado que interpone excepciones, defensas y recursos sin fundamentos serios, con la única finalidad de dilatar o entorpecer) innecesariamente un juicio muchas veces cuasi eternamente ${ }^{3}$; es asumir una conducta procesal de improbus litigatur.

\footnotetext{
${ }^{3}$ Traemos a colación un emblemático como harto conocido caso (que dicho sea de paso era sólo uno de la mayoría de los casos de antaño donde existía una marcada o exacerbada cultura litigiosa, iniciar y dilatar permanentemente los juicios; específicamente en la plena vigencia del Código de Procedimientos Civiles, porque de cierta forma el mismo cuerpo legal citado así lo permitía): Sucede que un abogado litigante de muy avanzada edad (cuyos casos eran casi los de siempre, porque eran los mismos al margen del avance inexorable de los días, semanas, meses, años...) decide retirarse del ejercicio abogadil, pero ocurre que paralelamente su nieto se titulaba de abogado, entonces decide dejarle en vida sus casos (increíblemente en esos tiempos dejar en herencia los casos de los letrados era una costumbre muy aceptada y admirada) pero no tomó en cuenta que su colega y nieto, diligente, pujante, de sangre nueva, imbuido e identificado con las nuevas tendencias jurídicas, culminaría con los mismos en meses. Pero grande fue su desconcierto, cuando lejos de obtener una felicitación de parte de su abuelo, recibió a cambio una severa llamada de atención y casi al borde las lagrimas le increpó: «iNieto de mi corazón, en ti están puestas las esperanzas de la familia, sin embargo, hondo es mi pesar, porque veo como nos defraudas clamorosa y desfachatadamente, porque los casos que dejé fueron los que atesoré y dilaté por décadas, es más, fueron mi prestigio, status y nuestro sustento. Ahora mi preocupación está en que encuentres o que busques a que te vas a dedicar para poder subsistir, si como abogado litigante no sirves!». Nótese el marcado comportamiento cuya relación con el tema del presente trabajo es muy notorio, como preocupante y reflexivo.
} 
Verbigracia, el litigante temerario es quien altera el proceso, pues, falsifica, corrompe, cambia, cercena, destruye o sustrae la prueba ya incorporada al mismo, o amenaza, coacciona, soborna o engaña a un testigo; porque de esa manera el magistrado probablemente decidiría muy distinto a lo que debiera (a lo justo), obviamente en perjuicio de la parte contraria.

Consecuentemente, el temerario procesal o «improbus litigatur», es quien ha actuado indistinta o concurrentemente con temeridad procesal o con malicia (mala fe) procesales. Por ende, consideramos válido utilizar el término maliciario procesal, como sinónimo de temerario procesal, dado que este ultimo abarca o incluye a la temeridad y a la malicia (mala fe) procesales.

\section{El artículo II2 («no deslindado») del código procesal peruano}

Solo para efectos académicos abordamos el tema que el legislador peruano (a diferencia de la temeridad procesal) no hace referencia expresa al término: malicia procesal, sin embargo, desde nuestro punto de vista sí lo hace pero utilizando un sinónimo (la mala fe), dado que el inc. 6 del art. II2 del Código Civil peruano advierte: «Se considera que ha existido temeridad o mala fe... cuando por cualquier medio se entorpezca reiteradamente el desarrollo normal del proceso» (el subrayado, resaltado y cursiva son nuestros). Así, consideramos que, la malicia, además de entorpecer el proceso, requiere ser reiterada. Referimos que es la mala fe o malicia la que se configura con la reiterancia mencionada textualmente en el citado artículo, ergo, la temeridad procesal (acto arriesgado, sin razón o fundamento y sin posibilidad de éxito) no significa lo mismo que la malicia o mala fe procesal, sino que es difícil comportarse reiteradamente como temerario en el proceso.

Empero, como afirmar que la mala fe que sanciona el Código Civil peruano, significa lo mismo que la malicia (o viceversa) no es suficiente; procedemos a realizar la fundamentación requerida. En primer lugar, necesitamos tener a mano el significado de mala fe que está relacionado con la maldad, la cual es «una acción mala e injusta»; y así también el de malicia que es (de forma concisa) «el empleo arbitrario u obstruccionista del proceso». En segundo lugar, tenemos que en dicha definición última hay dos términos que desarrollar (arbitrariedad y obstruccionismo). En tercer lugar, tenemos que: i) arbitrariedad, implica un «actuar contrario a lo justo, caprichoso o engreído», y ii) obstruccionista, nos habla de «dificultar, entorpecer, impedir, retardar o dilatar». En cuarto lugar, tenemos que la maldad es un acto malo o injusto, así como también el que la arbitrariedad y obstruccionismo denota injusticia. En quinto lugar, consecuentemente tenemos que mala fe y malicia son sinónimos.

Ahora, tomando como premisa dicha sinonimia (entre mala fe y malicia procesales) y dado que art. in2 del Código Civil peruano no solamente no menciona textualmente (como ya dijimos) la malicia, pero sí la menciona, diremos, utilizando un sinónimo: la mala fe. Pero el asunto no acaba ahí, va mas allá, porque en dicho artículo (que tiene siete incisos), el término mala fe solo es nombrado en el encabezado o inicio del mismo, consecuentemente, no precisa que incisos están referidos a la temeridad y cuales a la mala fe o malicia.

En ese sentido, utilizando las consideraciones y precisiones conceptuales anteriormente expuestas, realizamos los deslindes necesarios de los siete incisos que contiene el art. II2 del Código Civil peruano, que solo se limita a indicar «se considera que ha existido temeridad o mala fe en los siguientes casos»:

i) «Inc.1. Cuando sea manifiesta la carencia de fundamento jurídico de la demanda, contestación o medio impugnatorio».

Consideramos que el presente inciso está referido a la temeridad procesal. 
ii) «Inc. 2. Cuando a sabiendas se aleguen hechos contrarios a la realidad».

En este inciso, para nosotros, está dando a conocer la temeridad procesal.

iii) «Inc. 3. Cuando se sustrae, mutile o inutilice alguna parte del expediente». Nuestro punto de vista es que este inciso se refiere a la temeridad procesal.

iv) «Inc. 4. Cuando se utilice el proceso o acto procesal para fines claramente ilegales o con propósitos dolosos o fraudulentos».

Este inciso es considerado por nosotros como malicia o mala fe procesal.

v) «Inc. 5. Cuando se obstruya la actuación de medios probatorios».

El presente inciso, para nosotros, está avocado a la mala fe o malicia procesal.

vi) «Inc. 6. Cuando por cualquier medio se entorpezca reiteradamente el desarrollo normal del proceso; $\gamma^{»}$

Este inciso, a criterio nuestro, es correspondiente con la malicia o mala fe procesal.

vii) «Inc. 7. Cuando por razones injustificadas las partes no asisten a la audiencia generando dilación» (Inciso agregado por el Artículo 2 de la L. N²6635, en fecha 23-06-96).

Este inciso, es a nuestra consideración, acorde con la mala fe o malicia procesal.

\section{Temeridad y malicia vs. principios procesales}

En primer lugar, tenemos que la temeridad y malicia procesales se identifican con la farsa, con la estafa en el proceso, con la ilegalidad, con el abuso del derecho. En consecuencia, son totalmente contrarias a los principios procesales que salvaguardan los derechos de las partes y de terceros, principios que pueden entenderse a nivel genérico, o específico, es decir, ya sea a nivel de un proceso constitucional $u$ ordinario.

Empero, en segundo lugar tenemos que respecto de los principios procesales, Devis Echandía (I984), afirma la importancia de los principios de la buena fe y la lealtad procesales (este último, denominado también, principio de moralidad (Morales Godo 2005) y principio de conducta procesal): La ley procesal debe sancionar la mala fe de las partes o de sus apoderados, estableciendo para ello severas medidas, entre ellas la responsabilidad solidaria de aquellas y éstos, y el juez debe tener facultades oficiosas para prevenir, investigar y sancionar tanto aquélla como el fraude procesal (Espinoza Zevallos 2005).

En ese sentido, no se puede accionar, en sede judicial, con temeridad y/o malicia procesales si se es respetuoso de los principios señalados, ya que la malicia y temeridad procesales son totalmente opuestas o antagónicas respecto de los principios de la buena fe y la lealtad procesales.

\section{Temeridad y malicia procesales en la literatura}

Nadie como Carlos Ramos Núñez para deleitarnos magistralmente al recorrer los pasajes de diversas como no pocas obras literarias asociadas al mundo jurídico, en efecto 
menciona de la obra «El tigre blanco» de Alonso Cueto: «El inescrupuloso Carranza resumía su práctica profesional en una frase peruana muy extendida entre quienes corrompen y quienes se dejan corromper: ¿cómo arreglamos? La expresión supone un tácito entendimiento entre los interlocutores que dan por sentado que, no obstante cualquier impedimento legal o ético, llegarán a un acuerdo que los sustraiga de la norma» (Ramos Núñez 2007). El subrayado, resaltado y cursivo, son nuestros.

La frase peruana (en forma interrogatoria) referida anteriormente delata o da a entender que la misma se convierte en un agujero negro donde lógica y lamentablemente se entiende tiene cabida tanto la temeridad, como la malicia procesales y más, por decir lo menos.

\section{Teoría del abuso del derecho}

\section{I. Definición}

Esta teoría refiere que cuando se acciona procesalmente con mala fe (mala fe) y/o temeridad, se incurre en abuso del derecho, es decir, se comete dicho abuso debido a la utilización del derecho de una manera indebida, anormal, innecesaria, excesiva, perversa, injusta, desmedida, transgresora, antifuncional, impropia o inadecuada.

Cabe dejar constancia que generalmente dichas inconductas perturbadoras del proceso (que son producto del uso irregular, exagerado e ilimitado de un derecho subjetivo) no son abiertamente antijurídicas y requieren en consecuencia una supervigilia minuciosa y permanente del proceso. Por otro lado, señalamos que el referido acto denominado o calificado como abuso atenta o es contrario al análisis económico del derecho y a la sociedad, al margen de ser abiertamente alejado de la finalidad de la ley, legalidad y justicia.

Gonzalo Fernández de León (I972), dice que desde el punto de vista jurídico, abuso es «el hecho de usar de un poder o facultad, aplicándolos a fines distintos de aquellos que son ilícitos por naturaleza o costumbre».

Así también, Couture (I983), define al abuso del derecho como «una forma excesiva y vejatoria de acción u omisión de parte de quien, so pretexto de ejercer un derecho procesal, causa perjuicio al adversario, sin que ello sea requerido por las necesidades de la defensa».

Para Raúl Chanamé Orbe (2002), el abuso del derecho es «una figura por la cual, se ejerce un derecho fuera de la finalidad para la que fue concebido, atropellando un interés legítimo, aún no protegido jurídicamente. Cuando el titular de un derecho lo ejercita con el fin de dañar a otro, no necesariamente con el fin de beneficiarse».

Luís Ribó Durand (1987), refiere acerca del abuso del derecho como «la posibilidad de que un sujeto de derecho, al hacer uso del poder jurídico que conlleva el derecho subjetivo del que es titular, ejercite dicho poder de forma antisocial».

Henri Capitant (I986), entiende que el abuso del derecho es «un acto material o jurídico dañoso, que sería considerado lícito si se atendiese a un examen objetivo y formal de él, pero que es ilícito porque el titular del derecho lo ejerce con la intención de perjudicar a otra persona (proceso vejatorio)».

Pedro Adrián Infantes Mandujano (2000), advierte que «el abuso del derecho consiste en la ilicitud de ejercer una facultad, potestad, derecho mas allá de lo permitido moral o legalmente, también aprovecharse de una situación u objeto con la misma finalidad. El abuso 
puede ocasionarlo una persona teniendo como base un hecho lícito pero con finalidad ilícita... que se sale de los límites de la justicia, la equidad, la ley y la razón».

Cabe señalar que el proceso evolutivo de la aceptación o reconocimiento de la conducta procesal abusiva o excesiva como tal, ha sido motivo de arduas y encendidas discusiones entre: i) la doctrina procesal liberal individualista y ii) su homóloga contemporánea; donde la primera alegaba que no había motivo de positivizarla ya que sus efectos únicamente tenían que ser aceptados so pretexto del deber de asumir el costo del proceso, y a su vez la segunda abogaba por la necesidad de proscribir dicha inconducta procesal, vía prohibición y sanción legal. Ganadora de dicha confrontación resultó faustamente triunfante la segunda, es decir, la contemporánea/moralizadora del proceso propia de la Escuela eficientista del proceso civil; además de contener un loable propósito jurídico social solidario.

Por otro lado, consideramos, respecto del nomen juris «abuso del derecho», que las denominaciones más apropiadas son: «abuso del proceso», «abuso en el proceso» o «abuso de los derechos procesales», dado que si bien es cierto que lo que se persigue es modificar, prolongar o postergar -sacando ventaja de manera ilegitima- la sentencia o sus efectos, para tal propósito se hace uso abusivo de inconductas a nivel procesal.

Señalamos que el abuso del derecho, se presenta como opuesto o antagónico al principio de la proscripción del abuso del proceso -este principio se fundamenta en el deber de lealtad, probidad y buena fe procesales- y es el producto de la consecuencia de la temeridad procesal. Dicha dañosidad (probada) se efectiviza al limitar la aplicación de la finalidad del derecho que es la justicia; así, el -en su momento- invocamiento de Piero Calamandrei, acerca del insoslayable retorno de la priorización de la justicia en el proceso; corrobora lo dicho.

Cabe aclarar que la ausencia de intervención o denuncia oportuna de inconductas procesales conllevará a su convalidación, y su advertimento debe arribar a la eventual nulidad de las mismas, además de las responsabilidades civil, penal y administrativa en que incurre el sujeto del proceso abusivo del derecho. Así también, se debe tener en cuenta que la sanción al abuso del derecho debe ser entendida y aplicada con una naturaleza excepcional y no prioritaria o generalizante, ya que básicamente desvirtuaría su función correctiva.

\section{VIII.2. Naturaleza jurídica}

Es curioso, por decir lo menos, el amplio abanico de teorías que postulan argumentos para intentar determinar la naturaleza jurídica del abuso del derecho, lo que nos da una idea muy clara de la dificultad y amplitud para arribar a dicha empresa. Inclusive, actualmente la doctrina aún no es conteste respecto de la precisión de la uniformidad de su naturaleza jurídica.

En ese sentido, a decir de Abraham Luís Vargas, quien, citando a Ival Rocca, enumera una serie de teorías que reclaman para sí la exclusividad de adjudicación de la naturaleza jurídica del abuso del derecho: «i) del acto sin derecho, ii) del exceso ilegítimo, iii) de la extralimitación, iv) del acto ilícito, v) de la culpa, vi) del dolo genérico, vii) del dolo intención de perjudicar, viii) del dolo intención de beneficiarse, ix) del dolo intención antisocial, x) del exceso de destino, xi) del interés, xii) del enriquecimiento sin causa, xiii) de la mala fe, xiv) del riesgo creado, y xv) del fin económico social» (Vargas 200I, pp. 296-297).

\section{VIII.3. Origen y evolución}

Si bien es cierto que la teoría del abuso del derecho fue ideada en el derecho romano en respuesta a la utilización ilimitada del derecho subjetivo en el proceso, ésta aparece inicialmente 
en la jurisprudencia francesa, pasando -a inicios del siglo XVIII, cuando el Landrecht de Prusia de I794 se convierte en el pionero, de los ordenamientos jurídicos del mundo, en establecer taxativamente el abuso del derecho como principio -a positivizarse en las legislaciones europeas y latinoamericanas, principalmente; no logrando ser incluida aún en el derecho del commun law (donde utilizan la teoría de los actos ilícitos o la indebida interferencia en los intereses ajenos para combatir el abuso del derecho).

Por otro lado, tenemos que la jurisprudencia del antiguo derecho francés aplicó en numerosos casos el principio del abuso malicioso (Bustamante Alsina I992). Luego, el Código Civil alemán (Bürgerliches Gesetzbuch, denominado también $B G B$ ) señaló: «el ejercicio de un derecho es inadmisible cuando solo puede tener por fin dañar a otro», siendo refrendado por su correspondiente par adjetivo (Zivilproze-ordnung, conocido también como ZPO) al establecer la posibilidad del magistrado de derivar argumentos de prueba de la conducta procesal de las partes atendiendo al contenido íntegro de los debates. Posteriormente, también hicieron lo propio sus pares civiles suizo, soviético, peruano e italiano, entre otros. En ese sentido, tenemos que cuasi recientemente la Constitución peruana (I993) incluyó en su texto la prohibición del abuso del derecho, en su artículo I03 in fine. Es así como progresivamente el abuso del derecho demuestra claramente su avance desde la doctrina, pasando por la jurisprudencia, para finalmente lograr positivizarse.

Este proceder procesal anómalo (abuso del derecho), supone el ejercicio de un derecho subjetivo excediéndose de sus naturales y adecuados limites, lo que genera perjuicio a terceros, sin utilidad alguna para el titular... Es famosa la tesis de Calvo Sotelo, que preparó para la posteridad el terreno a la no menos destacada sentencia del Tribunal Supremo español, del I4/02/I944 que modificó el criterio -de quien ejercita su derecho no daña a nadie-, a partir de cuyo momento, ya acogiendo unas veces un criterio objetivo, ya en otras, el subjetivo, se instauró una corriente judicial de sanción al abuso; preparando así el terreno para la posterior incorporación de la condena del abuso del derecho en el Código Civil español (Palés 2002).

VIII.4. Sujetos que incurren en abuso de derecho procesales:

Consideramos que pueden incurrir en uso abusivo del proceso la totalidad de los sujetos

i) Las partes.- Cuando solicitan o reclaman derechos inexistentes o ilegales o al quejar indebida o infundadamente a un magistrado ante la Oficina de Control de la Magistratura OCMA- (en este tipo de quejas incurren también no pocos abogados).

ii) El abogado. ${ }^{4}$ A través de la interposición de recurrentes medidas cautelares, el planteamiento de ilegales recusaciones, accionar judicialmente a través los recursos más perjudiciales para la parte contraria, de quebrantamiento de procesos, reclamar un derecho sin haber agotado la vía previa, interposición de recursos de todo y por todo con el evidente propósito de dilatar o impedir la finalización del proceso o la ejecución de una sentencia.

iii) Los auxiliares jurisdiccionales.- Mediante el ocultamiento de documentos.

iv) Los notificadores.- Al notificar en lugar distinto a la verdadera dirección de la otra parte.

v) Los terceros.- A través de inconductas procesales de peritos, y

\footnotetext{
$4 \quad$ Sin embargo, por obvias razones, es preciso tomar en cuenta que no es sencillo establecer una clara, precisa o exacta diferencia o línea divisoria entre los actos o conductas temerarias o de mala fe de las partes y los abogados.
} 
vi) El juez.- Al correr excesivamente traslados a la partes, excesivo rigor en la formalidad al rechazar recursos o declarar nulidades recurrentemente, admitir o rechazar medios probatorios abiertamente procedentes o improcedentes respectivamente, incurrir en morosidad judicial injustificada o no sancionar (omisión cuasi cómplice) el accionar procesal abusivo de cualquiera de los sujetos señalados.

VIII.5. Formas para determinar dicho abuso

Contamos con tres parámetros, maneras, modalidades o criterios para establecerlo:

i) Subjetiva.- Mediante la cual el sujeto del proceso ejercita una conducta procesal abusiva con clara intencionalidad o culpa de dañar a otro.

ii) Objetiva.- En esta modalidad el sujeto procesal acciona abusivamente en el proceso consiguiendo violar, eliminar, modificar o afectar la finalidad del derecho.

iii) Ecléctica.- Considera que el sujeto procesal comete abuso del derecho al querer (y lograr) perjudicar a otro o al distorsionar/desbordar el fin del derecho. En otros términos, el presente criterio ecléctico o mixto considera la simultaneidad o concurrencia de las anteriores modalidades descritas.

\section{VIII.6. Efectos del abuso de derecho}

Respecto de los efectos que se generan como consecuencia de la aplicación o acción omisiva del abuso del derecho o procesal, Juan Alberto Rambaldo nos da luces al acotar (Rambaldo 200I, p. 227):

«Es lógico que varíen los efectos de la comisión del abuso procesal, según:

i) La oportunidad en el que el mismo se cometa (antes o durante el proceso),

ii) El tiempo en que se hubiese tomado conocimiento de la realización del acto abusivo,

iii) La magnitud $y$,

iv) La reparabilidad del daño causado».

\section{Costas, costos, multas, responsabilidades y sanciones}

\section{IX.I. Costas}

Según el Código Procesal Civil peruano (art. 4IO), las costas están constituidas por i) las tasas judiciales, ii) los honorarios de los órganos de auxilio judicial y iii) los demás gastos judiciales realizados en el proceso.

La costas o gastos son de aplicación a la parte vencida (se aplican de oficio), tanto como los costos, pueden ser convenidos por las partes cuando el proceso concluye por transacción o conciliación. Notificadas las costas deben ser canceladas de manera inmediata, caso contrario se podrá cobrarlas por la vía forzosa.

Hugo Alsina (I96I) sostiene que «en los inicios del antiguo derecho romano no se conocían las costas, cada litigante abonaba sus propios gastos... tampoco se conocieron en Francia 
hasta la edad media, en que se comenzó a aplicar una multa a quien sucumbía en el pleito, de donde derivó la costumbre».

El maestro Chiovenda (2004), manifiesta que «la máxima de que el vencido ha de pagar necesariamente al vencedor los gastos o costas del juicio corresponde ya a la última fase del derecho romano. Anteriormente la condena en costas, no se imponía sino al vencido temerario, entendida la temeritas, al igual que la calumnia, como consecuencia de lo injusto. En días más remotos aún no tenía lugar el reembolso de gastos entre las partes contendientes, pues quedaban a cargo del vencedor y del vencido, a no ser que uno de ellos tuviera derecho a exigirlas de un tercero ajeno al pleito, pero responsable de él».

Para Jaime Guasp (I998), «las costas son una parte de los gastos procesales: una species de un genus más amplio que abarca todos los desembolsos de carácter económico que el proceso puede producir».

Según explica Pedro Sagástegui Urteaga (2003), «la expresión costas tienen varios sentidos: i) Cantidades fijas e inalterables que se adeudan al Estado con ocasión del proceso ii) Condena accesoria impuesta en sentencia por su conducta procesal iii) Indemnización a cargo de la parte vencida en proceso civil a favor del vencedor, cuando el juez condena al resarcimiento de esa parte de los gastos causados iv) Es propio de los sistemas del civil law. En el derecho anglosajón se denomina expensas ofees».

Por otro lado, Raúl Chanamé Orbe refiere que las costas son «gastos ocasionados a las partes litigantes con ocasión del proceso judicial, que se cuantifican en un valor económico. Las costas son: i) procesales (actuaciones y diligencias) y ii) personales (honorarios de abogado, etc.)» (Chanamé Orbe 2002, 269).

Henri Capitant, señala «costas es el conjunto de gastos tasables efectuados por las partes en el curso o con ocasión de un juicio y que constituyen el objeto de una condena especial en el fallo; en principio se ponen a cargo de la parte vencida» (Capitant I986, 269).

\section{2. Costos}

Se debe entender por costos genéricamente como una indemnización impuesta por el magistrado como resarcimiento. Sin embargo, el Código procesal civil peruano (art. 4II) establece que son costos del proceso el honorario del Abogado de la parte vencedora, más un cinco por ciento destinado al Colegio de Abogados del Distrito Judicial respectivo para su Fondo Mutual y para cubrir los honorarios de los Abogados en los casos de Auxilio Judicial.

Couture señala «los costos son I.- Cantidades variables que como los honorarios profesionales, se adecuan a los que prestan servicios a los litigantes o a la justicia. 2.- Condena accesoria que el juez impone a quien ha litigado con malicia que merece la nota de temeridad, o en los casos en que es preceptiva por disposición de la ley. 3.- Indemnización que debe el vencido al vencedor cuando el juez, por ministerio de la ley o por apreciación de la conducta de aquél en juicio, condena al resarcimiento de esa parte de los gastos causídicos» (Couture I983, I86-I87).

\section{IX.3. Multas}

Se encuentra constituida por una sanción económica con la singularidad de estar destinada a ser ingresos propios del Poder Judicial. Sin embargo, a diferencia de las costas, no está regulada la exoneración de la misma. En consecuencia, se entiende que el juez debe ponderarla debidamente para no ocasionar angustias económicas excesivas en la parte vencida. 
Henri Capitant afirma que multa de procedimiento «es una multa considerada, a menudo como una variedad de la civil, y cuya función es asegurar el juego regular de un procedimiento, ya sea obligando a cumplir una formalidad o previniendo el ejercicio abusivo de un recurso» (Capitant I986, 382).

Antiguamente las costas importaban una suerte de prohibición de imponer otra sanción como sería la condena a pagar un resarcimiento suplementario (multa). Sin embargo, en la actualidad es casi de común aceptación en el derecho latinoamericano que contempla a su vez la temeridad procesal. Así por ejemplo: el artículo 22 de la Ley colombiana 446 de ig9 8 establece lo relacionado a la imposición de multas por entorpecer el normal desarrollo del proceso, obstruir la practica de pruebas, entre otros.

\section{IX.4. Responsabilidades}

La temeridad y malicia (mala fe) procesales se ubican en el Derecho de Daños, ocasionándose consecuentemente daños en todos los sujetos de un proceso judicial, aunque mayormente en el demandante y demandado.

El litigante que incurre en temeridad y/o malicia (mala fe) procesales abusa del derecho en perjuicio de la contraparte y/o terceros; consecuentemente es responsable por dicho acto a nivel civil, penal y administrativo.

Pero, cabe señalar que el daño que ocasiona es un daño material y no moral. Además, incurren en temeridad y malicia procesales quienes hayan actuado de manera dolosa, fraudulenta y no por culpa. Es decir, tienen que haber obrado con plena conciencia y voluntad de querer hacerlo. Así, traemos a colación el inc. 5 del art. 50 del Código Procesal Civil peruano, que indica: «son deberes de los jueces en el proceso: sancionar al abogado o a la parte que actúe en el proceso con dolo o fraude».

\section{IX.5. Sanciones}

Es importante precisar que los sujetos del proceso que incurren en temeridad o malicia procesales, son pasibles de sanciones como la multa. Así, citamos el inc. I ab initio del art. 53 que trata sobre las facultades coercitivas del juez y que en mérito a ellas puede «imponer multa compulsiva y progresiva destinada a que la parte o quien corresponda, cumpla sus mandatos con arreglo al contenido de su decisión».

La parte pertinente del inciso del artículo mencionado en el párrafo anterior, es aplicable cuando por ejemplo: el juez advierte que se está incurriendo en temeridad o malicia procesales o se pretende hacerlo, entonces, se hace saber al o los responsables conminándolos a que se abstengan de continuar o insistir en dicha actitud, con el apercibimiento de imponer multa como sanción.

\section{Normatividad aplicable al caso peruano}

Tenemos que en lo que respecta a la exigencia de no incurrir en temeridad y/o malicia (mala fe) procesales, diversos cuerpos normativos del Estado peruano se ocupan de ella, tanto a nivel de la jurisdicción ordinaria (de instancia plural, subjetiva y difusa por constitucionalidad), como la constitucional (de instancia única, de urgencia, objetiva y difusa propiamente dicha), ya sea en sus respectivos títulos preliminares o en su articulado. 
Sin embargo, es preciso dejar en claro que si bien es cierto que los temas de la temeridad procesal y malicia (mala fe) procesales se encuentran contemplados en el Código Procesal Civil peruano de 1993 (art. II2), también es cierto que dicho ejercicio irregular del derecho no necesariamente figura expresa o no expresamente en el articulado de la totalidad de los demás códigos procesales peruanos (salvo el caso del Código Procesal Constitucional, art. 56) o leyes orgánicas (salvo el caso, además, de la Ley Orgánica del Poder Judicial, art. 288); empero, ello no debe significar que el articulado referido a la mala fe (malicia) y temeridad procesales del Código Procesal Civil referido no debe ser aplicado por los códigos procesales que no lo contemplen; dado que la Primera Disposición Final y Complementaria establece: «las disposiciones de este Código se aplican supletoriamente a los demás ordenamientos procesales, siempre que sean compatibles con su naturaleza». En consecuencia lo concerniente a la temeridad y malicia (mala fe) procesales regulado en el Código Procesal Civil peruano es de aplicación a todos los demás códigos procesales peruanos, salvo que la naturaleza incompatible de alguno(s) lo impida.

Por si fuera poco, tenemos que considerar que el Código Civil peruano regula el ejercicio abusivo del derecho -art. II de su Título Preliminar- (que se debe entender como la consecuencia del accionamiento procesal temerario o malicioso) y más aún finalmente, la Constitución Política peruana de I993 también contempla el abuso del derecho (art. IO3). Consecuentemente, si la Constitución Política peruana no ampara el abuso del derecho, éste no debe ser amparado por ninguna fuente del derecho peruano tanto en sede judicial o extrajudicial.

Acto seguido, citaremos el bloque de constitucionalidad5 respectivo:

i) Constitución Política peruana.- El art. IO3 sobre el abuso del derecho.

ii) Código Procesal Constitucional peruano.- El art. 56 sobre las costas y costos.

iii) Código Civil peruano.- El art. II de su Título Preliminar refiere acerca del ejercicio abusivo del derecho.

iv)Código Procesal Civil peruano.- El art. IV de su Título Preliminar señala los principios de iniciativa de parte y de conducta procesal, el art. Iog que trata sobre los deberes de las partes, abogados y apoderados, el art. iाo que regula la responsabilidad patrimonial de las partes, sus abogados, sus apoderados y los terceros legitimados, el art. III que norma la responsabilidad de los abogados, el art. II2 que refiere acerca de la temeridad o mala fe, el art. 4IO acerca de la constitución de las costas, 4II respecto de la definición de los costos, 4I2 acerca del Principio de la condena en costas y costos, 4I3 sobre la exención y exoneración de costas y costos, 4I4 precisa los alcances de la condena en costas y costos, 4I5 acuerdo sobre costas y costos, $4 \mathrm{I} 6$ desistimiento y abandono en la condena en costas y costos, 4I7 liquidación de las costas, 4I 8 procedencia de los costos, 4I9 pago de las costas y costos, 420 literalidad y destino de la multa, 42I unidad de pago aplicable a la multa, 422 liquidación y procedimiento de la multa y 423 pago de la multa.

v) Ley Orgánica del Poder Judicial peruano.- El art. 284 que versa sobre la función de la abogacía y derecho de defensa, el art. 288 que trata sobre los deberes que debe observar el abogado patrocinante y el art. 292 referido sobre la sanción disciplinaria a abogados.

vi)Código de Ética de los Colegios de Abogados del Perú.- El art. 5 refiere acerca del abuso de procedimientos de los abogados y el art. 32 señala lo concerniente al descubrimiento de engaño o equivocación durante el juicio.

vii) Principios Básicos sobre la Función de los Abogados de las Naciones Unidas ${ }^{6}$.- El art. 26 y el 27 tratan sobre las actuaciones disciplinarias de los letrados.

\footnotetext{
${ }^{5}$ El bloque de constitucionalidad está compuesto por el conjunto de normas que acompañan y descifran a la Constitución. Este bloque es la resultante de la suma de la Constitución y las normas interpuestas o de desarrollo.

${ }^{6}$ Aprobados por el Octavo Congreso de las Naciones Unidas sobre Prevención del Delito y Tratamiento del Delincuente, celebrado en La Habana (Cuba) 27/ 08/ I990- 07/09/1990.
} 
viii) Anteproyecto del Código Procesal Civil Modelo para Iberoamérica7 ${ }^{7}$ - El art. 5. que versa sobre la buena fe y lealtad procesal de los participes del proceso y el art. Art. 35 que contiene lo relacionado a la responsabilidad del Tribunal.

\section{Legislación extranjera}

i) Código de Procedimiento Civil Venezolano.- El atentar contra la lealtad y probidad en el proceso es regulado por el art. I7 de su Título Preliminar contemplando lo referido a su prevención y sanción.

ii) Código Procesal Civil italiano (Códice di Procedura Civile).- Establece acerca del comportamiento de las partes en su art. II 6 , párrafo $2^{\circ}$.

iii) Código de Procedimiento Civil boliviano.- En su art. 4 señala las facultades especiales de los jueces y las partes.

iv) Código Deontológico de los Abogados de la Unión Europea ${ }^{8}$ - En el epígrafe 2.2. de sus Principios Generales estipula la importancia de la confianza e integridad moral del abogado.

v) Código Procesal Civil brasileño (Código de Processo Civil do Brasil o Institui).- Refiere sobre el litigante de mala fe, en su art. I7. mala fe.

vi) Código General del Proceso uruguayo.- En su art. 5 menciona el actuar procesal de

vii) Ley de Enjuiciamiento Civil española.- El art. 247 contiene el tema del respeto a las reglas de la buena fe procesal.

viii) Código Procesal Civil y Comercial argentino.- En su art. 29 aborda el tema de la recusación maliciosa.

ix) Código de Procedimiento Civil colombiano.- Traemos a colación el art. 73 el cual regula las costas del proceso del apoderado que actúe con temeridad o mala fe.

\section{Criterio del Tribunal Constitucional peruano}

Antes de revisar las jurisprudencias del Tribunal Constitucional (TC) en materia de temeridad y malicia (mala fe) procesales, es necesario tener presente que dichos fenómenos tienen como saldo a diez abogados recientemente sancionados por dicho Tribunal por promover acciones judiciales sin sentido, con sanciones que van desde la llamada de atención hasta multa pecuniaria. Además, el TC ha demandado a los magistrados del Poder Judicial a mantenerse alertas ante casos de temeridad procesal, los mismos que dicho sea de paso, lamentablemente van cada vez en aumento.

Es más, Juan Vergara Gotelli, miembro del TC, precisó que no se puede permitir que los abogados presenten temerariamente demandas que no tienen ninguna posibilidad de prosperar: «Ellos deben ser sancionados, porque son los conductores técnicos de la defensa y no deben pretender burlarse de los magistrados ni de sus patrocinados».

\footnotetext{
${ }^{7}$ Llevado a cabo en Montevideo en marzo de i988.

${ }^{8}$ Aprobado en sesión plenaria en Estrasburgo el 28/10/ı988, por el Consejo de Abogados de la Comunidad. (En ese entonces era Comunidad y no la de ahora Unión europea).
} 
A continuación hizo mención de dos casos: i) El primero, en el que un abogado presentó una demanda de hábeas corpus para una sociedad anónima (cuando es de común conocimiento que dicha acción de garantía solo es para proteger derechos de la persona y no para asociaciones o para empresas), y ii) El segundo, el de una acción de amparo en la que solicitaron una pensión de jubilación a favor de una persona que no tenía el número mínimo de aportaciones que señala la ley.

Es claro además, que por más exhaustiva que llegue a ser una investigación y/o aporte doctrinario, siempre llevará una sombra inmisericorde que lo señale, descalifique o condene por no mostrar, avocarse o abarcar también el ángulo práctico o concordar con la realidad referente al tema de investigación (peor aún cuando dicha realidad o lo que acontece en la práctica demuestra ser muy lejana o totalmente diferente a lo expresado). Cuando una investigación muestra el tipo de falencia señalado es conocida o achacada de no aterrizar o no llegar a aterrizar. Por lo cual haremos lo propio para evitar caer en dicha limitación, en los presentes temas de investigación.

En ese sentido, dejando constancia que si bien es cierto que la temeridad y la malicia -o mala fe-procesales se encuentran reguladas a nivel de jurisdicción ordinaria y también a nivel de jurisdicción constitucional, en la presente oportunidad:

i) Realizaremos un breve pasaje de veinticinco jurisprudencias del Tribunal Constitucional peruano (TC) referidas a los temas materia del presente trabajo, es decir, del segundo nivel señalado (selección realizada del periodo I995-2007).

ii) De dichas jurisprudencias para efectos de la presente investigación -dado que la inclusión del texto completo de las mismas, por su amplitud y cantidad, es obviamente impracticable-, hemos extractado (extraído textual y sistemáticamente, y no resumido o simplemente transcrito de sus respectivas sumillas), para un mejor entendimiento (más concreto, didáctico y ágil), las partes más relevantes o pertinentes.

iii) Además, cabe agregar que hemos resaltado y subrayado las partes más saltantes de las mismas e incidiendo más en los comportamientos de temeridad o malicia (mala fe) procesales, como en sus respectivas sanciones, que en los temas de fondo de dichas causas.

A continuación, pasaremos a revisarlas individualmente con la finalidad de determinar:

a) En qué medida el citado Tribunal, hace distingos o no al sancionar entre mala fe (malicia) y temeridad procesales.

b) En qué medida dicho Tribunal señala o distingue cuales de los siete incisos del art. iI2 del Código Procesal Civil peruano están referidos a la mala fe (malicia) procesal y cuales de los mismos, los son de la temeridad procesal:

i) Respecto de la resolución (Exp. $N^{\circ}$ 099-95 AA/TC), señalamos que los términos: i) «a sabiendas» de no poder modificar el fondo del fallo y ii) «presenta escrito»; nos da una clara señal de la comisión de temeridad, como efectivamente lo ha considerado el TC.

ii) En la resolución (Exp. $N^{\circ}$ 632-2001-AA/TC), se aprecia que el «inducir a error» al Tribunal es conducta inequívoca de temeridad ya que se entiende que el actor es conciente de no tener razón o fundamento. Sin embargo, no apreciamos la mala fe (malicia) que el TC menciona con que se haya actuado.

Consecuentemente, consideramos que para que esto suceda, lo más probable es que el TC no tiene bien en claro la diferencia entre mala fe (malicia) y temeridad, ya que parece considerar que ambos son sinónimos; peor aún cuando va más allá al señalar que se incurrió en «temeridad y/o mala fe» (dado que no es lógico, afirmar que algo se comporte válidamente como: 
«esto y aquello»; y a la vez o concurrentemente, es decir, al mismo tiempo, afirmar que ese algo sea también, «esto o aquello»).

En tal sentido, tiene que aclararse/deslindarse que sea «A o B» 0 «A $\gamma$ B» (pero no ambos a la vez), dado que es impreciso e incorrecto señalar que algo sea «A $\gamma / 0$ B», a la vez e indistintamente, además. Consecuentemente, no es válido sostener la doble y concurrentemente indistinta naturaleza de «A o $B », « A \gamma B » \mathrm{y} « A \gamma / 0 B »$.

Por otro lado, en la presente resolución (Exp. $N^{\circ}$ 632-2001-AA/TC) in comento el TC indica comisión de temeridad y/o mala fe, al respecto nos preguntamos si ello obedeció a un error mecanográfico incluir « $\gamma / 0$ mala fe» (en lugar de señalar únicamente la comisión de temeridad en la misma); ya que de lo contrario el asunto se evidenciaría más erróneo aún.

Si bien es cierto que lo relatado nos preocupa, no nos sorprende realmente, ya que el TC peruano presenta un desarrollo importante en derecho constitucional, más no aún en derecho procesal constitucional.

i) En la resolución (Exp. $N^{o}$ 1326-2001-AA/TC), se señala que: «no existiendo concepto que aclarar» el abogado «presenta solicitud», por consiguiente se ha incurrido en temeridad. Así también lo señaló el TC.

ii) En el presente caso (Exp. $N^{o}$ 200-2002-AC/TC), se repite lo mismo que en el anterior (Exp. $\left.N^{o} 1326-2001-A A / T C\right)$. Estamos de acuerdo con el TC. Es temeridad.

iii) En la presente resolución (Exp. $N^{o} 354-2002-A A / T C$ ), el TC afirma que se ha actuado de manera «obstruccionista $y$ temeraria». En este caso, si bien es cierto que entendemos que se ha litigado -a la vez- con malicia o mala fe (obstruir) y con temeridad; en ese sentido, nos extraña que el TC solo aprecie temeridad; porque el término «obstruccionista», parece ser utilizado solo para darle mayor énfasis a la temeridad.

iv) Aquí (Exp. $N^{o}$ 1200-2003-AA/TC), se obró con temeridad, ya que: «se actuó con conciencia de no tener razón». De igual opinión es el TC.

v) En este caso (Exp. $N^{o}$ 2620-2003-HC/TC), se «actúa sin tener fundamento». Concordamos con el TC, que señala que es temeridad.

vi) Aquí (Exp. $N^{\circ}$ 2851-2003-AA/TC) se puede apreciar que, al «presentar solicitud siendo conciente de no poder variar el fallo», se incurre según el TC en temeridad. De acuerdo.

vii) En esta jurisprudencia (Exp. $N^{o}$ 3338-2004-HC/TC), al actuar «obstruyendo o frustrando el proceso» de manera repetida (ya que incurren el ello varios abogados de las partes), se incurre en malicia o mala fe. Sin embargo, yerra el TC al esbozar el cometimento de temeridad. Consecuentemente, no estamos de acuerdo.

viii) En el presente caso (Exp. $\left.N^{0} 340-2005-P A / T C\right)$, se evidencia el «conciente accionar procesal duplicado pero en procesos distintos», lo que denota temeridad. En igual término lo considera el TC.

ix) En la presente resolución (Exp. $N^{\circ} 1660-2005-P A / T C$ ), el TC señala que hay temeridad al «pretender vía judicial acceder a un monto pensionario que no le corresponde por ley». Consideramos también haber lugar a temeridad. 
x) En el presente caso (Exp. $N^{o}$ 2016-2005-PA/TC), consideramos que: «presentar documento falsificado para reclamar otorgamiento de un derecho» es temeridad. De igual manera lo considera El TC.

xi) En el presente caso (Exp. $N^{\circ}$ 5088-2005-PA/TC), «accionar por la vía (amparo) no correspondiente por ley», revela temeridad según el TC. Opinamos lo mismo.

xii) En la presente resolución (Exp. $N^{\circ}$ 6712-2005-HC/TC), tenemos que: «solicitar inhibición cuando por ley no procede» revela temeridad. Luego, «dejar de presentar testigos» constituye mala fe o malicia. A continuación, «evitar relacionar la intervención de los miembros de su estudio a lo largo de los procesos penal $y$ constitucional con fines no correctos», evidencia también malicia o mala fe (en esta segunda oportunidad se configura la reiterancia exigida por ley para ser mala fe o malicia). Consecuentemente, consideramos que en el presente caso se ha obrado con temeridad y mala fe o malicia a la vez o concurrentemente. Sin embargo, el TC sanciona únicamente como temeridad. Lógicamente no estamos de acuerdo con el TC.

xiii) En el presente caso (Exp. $N^{o}$ 8094-2005-PA/TC), tenemos que: «accionar sin argumentos» y peor aún «solicitar anulación de acto jurisdiccional expedido conforme a ley», constituye temeridad. De igual manera lo entiende el TC.

xiv) En el presente caso (Exp. $N^{o}$ 294-2006-Q/TC), apreciamos que: «interponer recursos sin contar con legitimidad» y además, «sin tener legitimidad, accionar en queja»; denota en ambos casos, según el TC, temeridad. Suscribimos lo dicho.

xv) En este caso (Exp. $N^{\circ}$ 3165-2006-PHC/TC), apreciamos que: «desobedecer normas de conducta impuestas penalmente para alegar posteriormente vulneración del derecho de defensa o debido proceso», denota a nuestro entender temeridad. De igual opinión es el TC.

xvi) En la presente resolución (Exp. $N^{\circ}$ 4496-2006-PHC/TC), se aprecia la «conducta obstruccionista del actor quien para conseguir la prescripción de la acción penal hace uso de todos los recursos que la ley procesal prevé», la misma que corresponde a un actuar procesal malicioso o con malicia (por obstruccionista y reiterado). Sin embargo, el TC la considera como conducta temeraria y no maliciosa. No estamos de acuerdo con el TC.

xvii) En este caso (Exp. $N^{\circ}$ 5737-2006-PA/TC), tenemos que: «alegar vulneración de un derecho sin precisar la situación que meritúa tal vulneración», es incurrir en temeridad según el TC. Acerca de lo referido estamos de acuerdo.

xviii) En el presente caso (Exp. $\left.N^{o} 5784-2006-P A / T C\right)$, apreciamos que: «simular padecer una enfermedad para reclamar un derecho laboral que por ley no le corresponde», significa para nosotros, temeridad. Considera de igual modo el TC.

xix) En el presente caso (Exp. $N^{o} 5853-2006-P H C / T C$ ), observamos que el TC señala que: el «utilizar reiteradamente una vía procesal excepcional para cuestionar hechos iguales, habiendo algunos sido merituados oportunamente por el TC»; es evidenciar temeridad. Así también lo entendemos.

xx) Aquí (Exp. $N^{\circ}$ 6146-2006-PA/TC), el TC considera apreciar temeridad al «pretender (el demandante) iniciar un proceso de amparo respecto de una pretensión cuya tutela fue anteriormente solicitada en la vía ordinaria». Suscribimos lo señalado.

xxi) En el presente caso (Exp. $\left.N^{\circ} 8823-2006-P A / T C\right)$, tenemos que: «no acreditar las supuestas violaciones a derechos, supuestamente consumadas», implica accionar a nivel procesal con evidente temeridad. El TC también lo considera así. 
xxii) En el presente caso (Exp. $\left.N^{\circ} 10063-2006-P A / T C\right)$, ante un pedido de otorgamiento de pensión de invalidez, el TC al apreciar que el sistema procesal institucional involucrado para dicho fin presenta falencias, decide dictar la reglamentación o lineamientos correspondientes para salvar dicha problemática. En tal sentido, el TC realiza un adecuado ordenamiento, prevención e invocación (a los justiciables y entes involucrados) e efectos de evitar que en posteriores oportunidades se accione de manera ineficaz y por ende, poner en funcionamiento insulsamente el aparato jurisdiccional. Finalmente, queda claro que en el presente caso no se incurrió en temeridad, ni en malicia o mala fe procesales.

xxiii) En el presente caso (Exp. $\left.N^{\circ} 183-2007-P A / T C\right)$, tenemos que el «intento de inducir a error a los órganos judiciales», configura temeridad. Así también lo señala el TC. Pero el error deviene al señalar posteriormente que también se ha obrado con mala fe (malicia), ya que no se incurrió en esta última. Ergo, no concordamos con el TC en que existe también malicia o mala fe.

Luego de haber realizado el presente recorrido por las presentes jurisprudencias del TC podemos afirmar que en seis casos (I.- Exp. $N^{o}$ 632-2001-AA/TC, 2.- Exp. $N^{\circ}$ 354-2002-AA/TC, 3.-

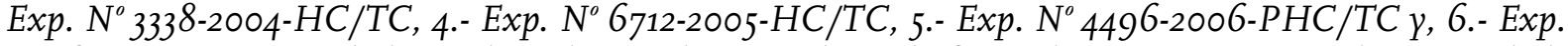
$N^{o}$ 183-2007-PA/TC), dicho Tribunal considera que la mala fe (malicia) es sinónimo de temeridad, o que se puede incurrir en la primera y la segunda conjuntamente y a la vez (es decir, al mismo tiempo o concurrentemente) incurrir en temeridad o mala fe (malicia), lo que nos lleva a determinar (respecto del análisis de las resoluciones referidas) que dicho Tribunal (TC) entiende equivocadamente que temeridad y mala fe (malicia) son sinónimos; lo cual como ya hemos expuesto no es exacto. Creemos que el error incurrido tiene por origen el articulo iI2 (no deslindado) del Código Procesal Civil peruano, ya que en su encabezamiento se señala que «incurren en temeridad $\gamma / 0$ mala fe...», sin embargo, en los siete incisos que consta dicho articulo no se precisa/deslinda cuales corresponden a temeridad y cuales a mala fe. Tal vez, por eso el TC, para abreviar o salir del paso, se limite a afirmar (en más de un caso) que se comete temeridad y/o mala fe sin determinar que acto o conducta específicamente se ha cometido, es decir, o temeridad o mala fe, o ambas.

En ese sentido, lo que el Tribunal Constitucional peruano ha sostenido y sostiene que es válido afirmar la doble y concurrentemente indistinta naturaleza de «A o $B »$, «A $\gamma B » \mathrm{y} « A \gamma / 0 B »$. Lo cual no es cierto, ni exacto, por decir lo menos.

Ergo, según lo esbozado, cabe insoslayablemente que nos hagamos la siguiente interrogante: ¿se encontrarán los señores magistrados -ordinarios y constitucionales-en condiciones de determinar la graduación de los perjudiciales efectos del incurrimiento de temeridad, mala fe (malicia) procesales o de ambas, $y$ por consiguiente, aplicar las amonestaciones o sanciones debidamente en tales casos, si anteladamente sabemos que no se puede diferenciarlas legalmente como se puede apreciar en los siete incisos «no deslindados» del art. 112 del Código Procesal Civil peruano?. Consideramos que la respuesta fundamentada, a la luz de la investigación y demostración del presente trabajo de investigación, es un rotundo y categórico no.

\section{Reflexiones finales}

Atravesamos, más que nunca, épocas de permanente vorágine, la misma que trae consigo muchos cambios a nivel político, económico, social, moral, lógicamente también a nivel jurídico y específicamente además, en el área jurídico procesal. Así, tenemos, que nuevas (y otras no tan nuevas, pero novedosas) corrientes jurídicas y no jurídicas, hacen sentir cada vez más su presencia (por su aporte al derecho, claro está) en el mundo del Derecho; verbigracia: el marketing 
jurídico, consistente en básicamente crear valor, ofrecer valor y ser el nexo entre el abogado y el mercado; cuya finalidad es crear, conservar clientes o patrocinados, garantizando un posicionamiento efectivo y perdurable.

También tenemos la corriente o teoría del neoconstitucionalismo ${ }^{9}{ }^{\text {Io }}$, además debemos señalar la importancia del coaching ontológico, disciplina que asiste al factor humano para ayudarle a obtener mejores resultados, trabajando profundamente en el dominio de ellos mismos, para darles acceso a sus puntos ciegos, nulos o débiles, en un aspecto o área determinada; consiguiendo con ello ampliar su perspectiva para la mejor toma de decisiones y acciones y lograr nuevas y cada vez más altas metas; renovando, estimulando, predisponiendo y potencializando a la persona.

Luego, imprescindible hacer breve referencia a la teoría del derecho global ${ }^{\text {II; }}$; por otro lado, cabe destacar lo concerniente al derecho deportivo, el mismo que es una rama especial del derecho

\begin{abstract}
9 «...De origen principalmente germano (Estado que aturdido y atrapado por la contemplación de las atrocidades del nazismo, no tuvo más que enmendarse), específicamente en la primera jurisprudencia del Tribunal Constitucional Federal alemán en I958; y su posterior desarrollo en Estados Unidos, Italia y parte de Latinoamérica. Aparece como un 'saludable despertar o concientización constitucional a favor de los derechos fundamentales $y$ donde los mismos se yerguen como eje central del sistema jurídico, y como sustento de fundamentación universal de irrebatible legitimidad' (que se presenta -a pesar de su denominación- no como una nueva pero si, ciertamente novedosa corriente o teoría jurídica de irradiación mundial), 'gracias' al limitado papel de la doctrina jurídica para poder explicar la justificación (o justeza) del Derecho en esta realidad o circunstancia postmoderna. Esta corriente jurídica se reafirma además, como una forma de sintonizar como Estados con un reciente orden jurídico -como consecuencia de la casi generalizada globalización en el mundo-, denominado 'Derecho Global' (entendido a su vez, como un 'nuevo' orden jurídico que opone una defensa radical de la dignidad, de la solidaridad, de la igualdad y de la justicia -seguridad jurídica- de la persona; como principios pilares jurídicos y que precisa de instituciones y de partidos políticos fuertes, transparentes y con amplia credibilidad). El neoconstitucionalismo como proceso de constitucionalización (que limita a los poderes estatales y/o protege los derechos fundamentales) del sistema o vida jurídico (a) de un Estado: i) Según Antonio Baldassarre, "Coloca a la Constitución como nuevo orden de valores', y ii) Según Víctor Bazán, 'Como la respuesta ante la tensión entre democracia y el constitucionalismo...'; deja atrás su función formal y hasta cierto punto cuasi expectante; para 'transformarse' en parte mas activa y protagónica del mismo y orientar de una manera mucho mas justa la convivencia ciudadana de nuestros días. El 'nuevo' constitucionalismo ya está presente en nuestro escenario constitucional. En ese sentido, recientes (y otros no tanto) reconocimientos de 'derechos constitucionales' como: i) 'al debido proceso', ii) 'las nuevas ocho modalidades de habeas corpus', iii) 'a la verdad', iv) 'a la personalidad jurídica', v) 'al agua potable'; vi) 'a la salud', vii) 'a la educación', viii) 'a la propiedad', ix) 'a la asociación' y x) del principio 'ne bis in idem' (en el Perú); así como, xi) 'el habeas corpus colectivo o protector de derechos difusos u homogéneos múltiples', (en Argentina); dan contundente prueba de ello...». (TORRES MANRIQUE, J. I. «Derecho global y neoconstitucionalismo: Teorías jurídicas contemporáneas» (en línea). http://www.derechoycambiosocial.com/revistaoI3/derecho\%2oglobal\%2oneoconstitucionalismo.htm).
\end{abstract}

Io Cabe agregar el último reconocimiento de derechos constitucionales del Tribunal Constitucional peruano (Exp. $\mathrm{N}^{\circ}$ 6r64-2007-HD/TC-29/08/2008), como es el desarrollo de los tipos del Habeas Data (H. D.), dividiéndolo en dos grupos: A).- Propios: i) H. D. Informativo.- Para recabar la información necesaria que permita a su promotor, a partir de éste, verificar si los datos del sistema están funcionando legalmente. Si no fuera así se solicitará información de las operaciones sobre los asientos registrados o sobre el sistema de información en si mismo; se subdivide en: i1) Finalista.Para conocer la finalidad para la cual se creó el registro, i2) Exhibitorio.- Por el que se indaga que datos de carácter personal se encuentran almacenados en un registro, i3) Autoral.- Para conocer a quien proporcionó los datos almacenados, ii) H. D. Aditivo.- Para agregar datos de información datos de carácter personal no registrados, puede ser: actualizador, aclarador o inclusorio, iii) H. D. Rectificador o correctivo.- Para corregir datos falsos, inexactos o imprecisos, iv) H. D. Exclutorio o cancelatorio.- Para excluir información de un banco de datos que el titular considera debe ser cancelada, v) H. D. Reservador.- Para asegurar que un dato correcta y legítimamente almacenado sea mantenido en confidencialidad; B).- Impropios: i) De protección al acceso de la información pública.

${ }^{\text {II }}$ «...Este nuevo Derecho se origina en el ius gentium (Derecho romano aplicado a los extranjeros y a los romanos en sus litigios con estos), se fundamenta en el ius cogens (Derecho de los Estados 'a cumplir necesariamente') y el ius commune (Derecho aplicado básicamente a los negocios jurídicos globales), para hacer frente a los desafíos contra las lacras sociales como: el terrorismo, las organizaciones criminales internacionales, la corrupción generalizada y el 'orden' hegemónico, principalmente. Luís María Bandieri, afirma que este 'Universal Law' tuvo su origen (en la Edad media) en el derecho romano compilado por Justiniano: El Corpus Iuris Civilis, fue el ius commune de su tiempo, luego pasó a ser el Derecho de la Unión Europea y ahora, el Derecho global. El Derecho Global se fortalece en los inicios de los noventa (Prosper Weil, señala que dicho ordenamiento combatió la existencia de una 'crisis jurídica multiforme' del sistema normativo internacional, que en ese entonces padecía el mundo), mediante el acuñe de nuevos paradigmas como: democracia liberal, libre comercio, derecho de libre autodeterminación de los pueblos, inviolabilidad de las fronteras y concertación entre las grandes potencias. Para posteriormente iniciar un franco desarrollo en este siglo XXI. 
que regula la actividad generada por las conductas y los vínculos entre todos los actores del deporte. Asimismo, protege jurídicamente al ser humano y sus relaciones con la práctica y las técnicas deportivas estableciendo reglas aplicables al desarrollo de esta importante disciplina, con el fin de lograr los beneficios para la persona y la sociedad (Varsi Rospigliosi 2008).

Asimismo, no podemos dejar de nombrar al análisis económico del derecho, el cual debe ser entendido como: «la aplicación de las teorías y métodos de la economía al sistema jurídico, el cual se basa en la triada maximización -mercado-eficiencia bajo un enfoque costo- beneficio social; buscando maximizar o hacer más eficientes los recursos en mundo de escasez de bienes y servicios. El análisis de costo-beneficio no implica únicamente el aspecto económico, sino los motores de la conducta humana: como bienestar y malestar. El AED analiza la norma, pero no en abstracto, sino en base a una consecuencia social concreta» ${ }^{12}$.

Sin embargo, preocupa como llama poderosamente la atención el hecho de que dichas teorías contemporáneas (que no son pocas -así como, no son todas las que están ni están todas las que son-, menos aún son prescindibles, pues varias son defensoras de la legitimidad, constitucionalidad, derechos y respecto de la persona y de la humanidad), no consigan contribuir, al menos en algo (directa o indirectamente), a concientizar o mejorar la actitud de los sujetos procesales, en el aspecto ético y de correcto accionar procesal en los juicios. Más aún si consideramos que en su tiempo Couture (en sus «Mandamientos del Abogado») ya advertía la importancia de la lealtad procesal del abogado para con su patrocinado, con el juez y la otra parte $^{\mathrm{I} 3}$.

En ese sentido, no podemos negar que experimentamos un profundo pesar y desazón, ya que: i) por un lado, tenemos que existen cada vez más y mejores tendencias (jurídicas y no jurídicas) y normatividad destinadas, directa e indirectamente, a mejorar o elevar el nivel del ejercicio profesional de los letrados (en términos de corrección procesal) y específicamente a combatir la legendaria y lamentablemente, más vigente que nunca, práctica de la temeridad y malicia (mala fe) procesales; y ii) por otro lado, las mismas no sólo no son estancas o decrecen, ya que peor aún, tenemos que, en honor a la verdad, denunciar que su incidencia está cada vez en aumento.

Además, la creciente incidencia de la temeridad procesal, no constituye más que el fiel y patético hecho de encontrarnos en una profunda crisis de valores (la misma que ocasiona un inmenso forado moral; disvalores que perjudican gravemente al sistema jurídico, a los sujetos procesales y a la sociedad), hace que muchas veces el abogado correcto, honrado y honesto sea visto como un «tonto»; así Carlos Ramos Núñez cita, en ese sentido la obra Un mundo para Julius de Alfredo Bryce Echenique: «Pericote Siles (...) un personaje risible pero feo, solterón, no muy rico, pero sobre todo, por honesto, vale decir por cojudo: el rasgo más imperdonable del fracaso... se levantaba entre sonriente y amnésico, desayunaba apurado y sabía que jugaba a llegar al estudio optimista y atareadísimo, saludando a secretarias, pidiendo llamadas telefónicas, que

La mundialización del 'nuevo orden jurídico', irrumpe en el escenario jurídico mundial y equivale a: autonomía, espontaneidad, nueva estabilidad y equilibrio, más social, menos estatal, sin fronteras y siempre bajo la base y el irrestricto respeto de los derechos fundamentales que otorga al ser humano como parte integrante del nuevo sujeto jurídico: La Humanidad. Esta 'teoría jurídica global', se conforma precisamente, como contrapunto de la dogmática, apelando a un mundo más justo, democrático y libre, basado en los principios de personalidad, igualdad, solidaridad, subsidiariedad, integración y autoridad; reconociéndose en un mundo completo, complejo, diferente, pero unido...». (TORRES MANRIQUE, J. I. «Derecho global y neoconstitucionalismo: Teorías jurídicas contemporáneas» (en línea). http://www.elnotariado.com/images_db/noticias_archivos/322.doc).

I2 TORRES MANRIQUE, J. I. Acerca del análisis económico del derecho (Aed) (en línea). <http://www.elnotariado.com /images_db/noticias_archivos/279.doc>.

${ }^{13}$ Consideramos que Couture se refirió únicamente a la lealtad que debería guardar el abogado, porque su óptica en dicho trabajo fue precisamente desde el letrado hacia los demás sujetos procesales. Dado que es bien sabido, que dicha lealtad debe ser estrictamente observada por todos los sujetos del proceso o que participan en el proceso. 
impresionaban a las secretarias, anunciando que les iba a dictar y fumando, ahí empezaba a creer nuevamente en lo del abogadazo, en lo del solterón interesante, en lo del play-boy, en que iba a recoger a la flight hostess, aventura para el club, así era Pericote» (Ramos Núñez 2007).

No en vano Lorenzo A. Gardela esbozó: «El abuso procesal y los demás vicios éticos del proceso no brotan por generación espontánea...provienen de nuestro medio social de nuestro propio mundo jurídico y forense y de nosotros mismos». En ese sentido, no nos imaginarnos acerca de la intensidad de sentimientos de decepción y frustración que seguramente deben experimentar muchos profesores de derecho procesal civil, práctica forense y constitucional, al ver a más de uno de sus ex alumnos, (hoy abogados) ejerciendo muy campantes y avezadamente con la camiseta del improbus litigator: abusando del proceso, demostrando que todas sus enseñanzas están siendo utilizadas de la manera más vil como equivocada.

Así, el encontrarnos atravesando una severa crisis de valores, reviste además cierta como evidente ausencia o relativismo de formación humana, la misma que se remonta hasta la educación que se da en los hogares, colegios y centros de estudios. Formación que nos hace además, añorar a la encomiable labor y misión que cumplió el desaparecido gran maestro Constantino Carvalho.

Pero, a la crisis de valores (verbigracia, de valores como: justicia, honradez, igualdad, buena fe, libertad, bien común, seguridad, equidad; entre otros), de formación y educación, lamentablemente se le tiene que agregar la grave crisis por la que actualmente atraviesa la carrera de derecho en el Estado peruano, puede deber su origen también a una afirmación simple, como ciertamente cuasi irrebatible: «ser abogado en el Perú es demasiado fácil, pero ejercer luego correcta y plenamente la profesión resulta muy complicado» (Mesinas Montero 2006).

El problema de la inconducta procesal proviene o se origina desde la educación o formación en la familia, ausencia o defecto de la ética de entrecasa (Cornejo 2008), y continúa a lo largo de los estudios primarios, secundarios, universitarios (pre grado), post grado, especialización; entonces es equivocado combatirlo sólo a nivel de pre o post grado. El problema de la crisis de la educación jurídica peruana también se debe a que erradamente se cree que la actualización, capacitación y especialización son solo una etapa (es decir, se niega su naturaleza de permanencia) en la vida profesional y el mismo se agrava al entender, estudiar, investigar, enseñar y ejercer el derecho sin tomar en cuenta su multidisciplinariedad.

En ese sentido, dicha vista panorámica nos da una clara señal de que la solución no debe estar dirigida al hoy, sino más bien al antes (es decir, priorizar la prevención a la mera represión o sanción).

Consideramos imprescindible agregar que la intolerancia, falta de prolijidad y rigor, desidia, apego a la cultura del mínimo o nulo esfuerzo y ausencia de estandarización académica de mínimos requerimientos en las distintas facultades de derecho del país le hacen un flaco favor para revertir dicha afirmación. Todo ello aunado a una aún ausente como urgente e impostergable verdadera política de Estado de formación, capacitación, y especialización jurídica en el Perú (la misma que en su momento propusimos y desarrollamos, Torres Manrique 2006). Además, la enseñanza del derecho debe asumirse utilizando la óptica de la enseñanza activa con materiales de enseñanza; pero debiendo prevalecer la pedagogía jurídica por sobre la enseñanza del derecho, por ser más amplia, ya que comprende i) la educación jurídica (formación con valores) y ii) la enseñanza del derecho (transmisión de conocimientos, Torres Manrique 2005). Enseñanza del derecho que desgraciadamente no se cumple mayoritariamente.

Por otro lado, es menester precisar que estos flagelos (temeridad y malicia -mala feprocesales) no son nuevos o de hace poco, como tampoco es de carácter exclusivo de nuestro país, más bien corresponde a una cuasi constante como patética realidad académica y educativa que cobra ribetes mundiales. 
Consideramos curioso (por decir lo menos), que el hecho mismo que muy pocos, juristas y no juristas, procesalistas y no procesalistas (sobre todo en nuestro medio), se hayan ocupado en desarrollar el tema de la temeridad y malicia (mala fe) procesales. Sin embargo, quizá se deba a una motivación de negación o esquive a tratar acerca de algo (conducta procesal temeraria o maliciosa) en que el mismo abogado mayoritariamente incurre. Actitud de apego a la negación que nos recuerda, los no pocos esfuerzos (no sólo de la comunidad latina) de crear un término (siquiera sólo uno) para poder denominar la «acción de decir la verdad», ya que a lo único que en una oportunidad se arribó fue a establecer el término «veracear» (que deriva de veraz), sin embargo, no tuvo mayor acogida. En consecuencia, hasta ahora no se cuenta con una palabra para específicamente significar la acción de decir la verdad. Sin embargo, abismal es la diferencia que se presenta cuando fue fácilmente posible denominar la «acción de negar o no decir la verdad»».

El juez (bajo el principio iura novit curia), más que ser el juez del juicio, del expediente o de la causa, debe ser primordialmente el juez del proceso (director), del debido proceso. El juez tiene la obligación de estar muy atento a este tipo de inconductas procesales. Además, cabe considerar, que lo mencionado representa un verdadero reto, una valla un tanto alta para superar pero no imposible, para ser aplicada diligente, oportuna y en la totalidad de los casos, porque valgan verdades, no sólo la elevada carga procesal (ya que el problema de la crisis del poder judicial tiene mas aristas) no le facilita para nada superar dicho reto. Sin embargo, huelga básicamente priorizar la prevención a la sanción, ya que las normas o el endurecimiento de éstas no conseguirán el cambio de resultados como de actitud.

Por otro lado, hasta pareciera que muchos letrados habrían perdido el norte o verdadero sentido de la profesión que es la «justicia y corrección», ya que muchas veces parecen estar más preocupados en adoptar o aparentar insospechadas y hasta risibles actitudes como formas idiomáticas que les son inapropiadas (utilizar una surte de latíñol pseudo jurídico, es decir, hablar en latín y español a la vez o alternadamente con palabras carentes de naturaleza jurídica) y totalmente ajenas (spanglish pseudo jurídico, es decir, lo mismo pero con la utilización del español e inglés); debido principalmente a que: i) dichas formas idiomáticas no son válidas como idioma oficial de Estado alguno ii) no corresponden necesariamente a terminología jurídica en inglés -al menos la mayoría - porque simplemente son palabras de uso diario y común traducidas al inglés e incluidas como lenguaje abogadil; peor aún cuando se fuerzan palabras no técnicas o jurídicas del inglés para adaptarlas al lenguaje técnico peruano, ii) solo es utilizada para proyectar una imagen distinta a la real o un supuesto elevado nivel profesional y académico jurídico que muchas veces ciertamente no se tiene, iii) al impostar dicha actitud lo único que se consigue es evidenciar una patética falta de madurez y propiedad no solo al expresarse (vulgarización del derecho y de la profesión de abogado), porque no es correcto que siendo abogados se expresen o conduzcan como si no lo fueran, y iv) demuestra una falta de respeto a la majestad de la profesión de abogado, a sus colegas y finalmente a ellos mismos.

Dicho comportamiento referido en el párrafo anterior, es exquisita, cruda, directa y ampliamente reseñado (advertencia: cualquier parecido del caso particular de un letrado con los hechos narrados, no se achacan únicamente a la tan mentada pura coincidencia, sino mas bien a la mera y triste realidad, además, invocamos recurrir, según el caso, sesudamente a la autocrítica y autoanálisis -nosotros ya hicimos lo propio respecto de los que nos toca-; así que quien se pica pierde), con la maestría que lo caracteriza, por el profesor Juan Guillermo Lohmann Luca de Tena: «(...)estando en la fila de los ascensores del edificio de los juzgados oí que una persona (supuse que abogado, pero dudo que letrado) le decía con énfasis a otra que venía a reclamarle a un juez porque éste le había dismisido la demanda de un caso que patrocinaba. Como su interlocutor asentía insinuando que coincidía con la apreciación, no quise resistirme a la

${ }^{14}$ Para denominar la «acción de negar o no decir la verdad», existe gran cantidad de términos, por ejemplo tenemos: mentir, engañar, embustear, trapalear, bolear, urdir, trufar, embrollar, burlar, timar, tapar, trapacear, embaucar... entre otros. GISPERT, C. -Director-. (2006): Diccionario de sinónimos y antónimos. Barcelona: Editorial Océano. 
curiosidad y agucé el oído por si había escuchado mal. Pero no me equivocaba, no: el enojado sujeto seguía acalorándose y protestando por lo del dismiss(...) después de unos minutos caí en la cuenta, anticuado y lerdo de mí, que lo a lo que se refería el abogado que con tanto lustre pretendía expresarse era a que el juez le había declarado inadmisible por no tener razón. ¡Inefable empleo del término dismiss, que en ingles se emplea a veces para significar el rechazo de un pedido! No puede refrenarme, porque mi paciencia es mucho más reducida que la fila en la que estaba. Y aún a riesgo de que me juzgaran de impertinente (que seguramente lo hicieron) me inmiscuí en el diálogo para decirle a quien así se expresaba que no era necesario recurrir a extranjerismos cuando tan bien nos podemos entender en español. (...) los abogados, desgraciadamente no nos quedamos a la zaga. En textos y manifestaciones orales, muchos parecer disfrutar acometiendo lengua o pluma en ristre contra nuestro castellano. Para no quedar como indoctos o faltos de buen estilo, desde antaño es casi de regla en nuestra profesión legal despachar de tanto en tanto unas palabritas en latín (o en lo que a él pudiera parecérsele, como decir prometo que lo he oído- que fulanito de tal había hecho algo de mutuo propio). Pero para estar desfasados hogaño hay que introducir algunos términos anglosajones. (...) para marketarse bien y estar apropiadamente rankeado el abogado que se precie no debe decir que ha preparado el estatuto, eso lo hace cualquiera. Antes bien debe prestigiarse, engolar la voz y afirmar que ha producido un documento con los by laws. Pero queda mejor aún si, le puntualiza a su oyente (esto es, lo llena de puntos) que por mail (y no por correo electrónico) la ha forwardeado (y no enviado o transmitido) un draft (iqué ordinario y chabacano suena eso de propuesta, proyecto o borrador!) del shareholders agreement, al que el urgido cliente (porque los closing de acuerdos no admiten dilaciones) podrá accesar en diligente uso de su avanzada y completísima palm. El abogado que en esta área ejerce ya no lo hace en Derecho Societario, que parece plebeyo o poco serio, sino que se dedica al corporative law. Porque lo suyo, ¡faltaría más!, es el mundo del business, que es más provechoso que los decadentes y manidos Derecho Civil, Comercial o Penal (...) la tarde del abogado transcurre entre meetings, conference calls y working papers. Además, ha tenido que ir a una repartición pública para que le fedateen un documento. Ocupado con tantas cosas, si su secretaria le avisa que un cliente le llama por teléfono le responde, contéstale que no me encuentro. Y la secretaria dirá: el doctor no se encuentra. Con lo cual quien llamó tal vez quede perplejo y preguntándose si debe buscar otro abogado, pues como el que lo atendía no se encuentra, sin duda se ha perdido, se ha extraviado sin saber dónde, o está tan perturbado que no puede encontrarse a sí mismo. Y claro, después del agotamiento que producen tales jornadas laborales a full con tanta fatiga de la sustancia cerebral como por cierto requiere esfuerzo de expresarse mal en dos idiomas, y como es viernes empieza el week end, el abogado no se puede quedar en stand by en lo que resta (por lo que falta de la noche). De modo, pues, que especula sobre que hacer, en vez de detenerse a pensar sobre sus alternativas de distracción. Pero decide irse a dormir, porque ha sido extenuante tener a las neuronas haciendo piruetas para entenderse en el nuevo Babel» (Lohmann Luca De Tena 2004).

Por otro lado, dado que el debido proceso se encuentra reconocido en sus tres dimensiones: i) «jurisdiccional», que garantiza un proceso debido a nivel judicial, arbitral y militar, ii) «administrativo», que garantiza lo propio en sede de la administración pública, iii) «corporativo particular», que garantiza también un debido proceso entre particulares; y tomando en cuenta que la normatividad referida solo se encuentra orientada a la comisividad de la temeridad y malicia procesales, es decir, sólo a nivel procesal jurisdiccional; concluímos lógicamente en señalar que no es óbice para que dichas negativas prácticas procesales no se encuentren presentes (o no tengan incidencia) en los niveles procesal administrativo y procesal corporativo particular.

La temeridad y mala fe (malicia) procesales no se encuentran debidamente deslindadas diferenciadas -en los siete incisos del artículo iı2 del Código Procesal Civil peruano. Es más, dicha situación (a juzgar por el análisis de sus respectivas jurisprudencias), tampoco la tiene clara el Tribunal Constitucional peruano. Además, a nuestro entender es injusto -tanto para los sujetos pasivos de la malicia, como para el derecho- que el inciso 6 del citado artículo exija que la misma 
tenga que ser «reiterada» para que se configure como tal. Así también es injusta para los mismos la no diferenciación señalada.

Además, cabe tomar en cuenta que la sola mención de seguridad cien por ciento (ya sea vía solicitud o promesa) acerca de la eventual culminación favorable de una causa judicial (salvo se trate de casos excepcionales, por propia naturaleza) nos da una señal inequívoca que lo que se pretende es utilizar todos los medios (temeridad y malicia procesales, incluidas) para la concreción de dicho cometido; es decir, no se puede prometer la seguridad absoluta de ganar un juicio, ya que el ejercicio del derecho tiene la naturaleza de medios y no de resultado.

No somos médicos, pero, nos atrevemos a mencionar (sin temor a equivocarnos) que la sociedad jurídica peruana (no solo peruana) yace infectada de los virus de la temeridad y malicia (mala fe) procesales: presa de los virus «temerarius» y «maliciarius», por así decirlo. Pero como en medicina el enfermo si desea curarse, es sabido, que en primer lugar debe aceptar que tiene o padece una enfermedad; en similares términos señalamos que la sociedad jurídica (no solo jurídica) solo podrá aminorar o combatir frontalmente a dichos virus si antes reconoce su situación actual - encontrarse envirada de ellos - (ya que lo peor que se puede hacer frente a un problema, mas aún si es evidente, es desconocerlo o negar su existencia); en consecuencia, nos queda realizar un previo mea culpa respectivo, ya que nada ganamos si optamos o reincidimos por la cuasi institucionalizada conducta o actitud de la no aceptación o negación de la realidad (de la desoladora realidad diremos).

Sólo hemos expuesto algunas ideas y reflexiones de temas (flagelos fundamentalmente de origen y práctica humanos) tan amplios, profundos como apasionantes, los cuales claman desde hace mucho aportes, pero sobre todo acciones que se caractericen como aseguren su oportunidad, utilidad, proporcionalidad, prudencia y excepcionalidad. No abrigamos quimeras que persigan la desaparición o eliminación pronta o lejana de la práctica de la temeridad y mala fe (malicia) procesales.

Es preciso dejar constancia que el presente escueto trabajo no contiene la aspiración de constituirse en una especie de «Teoría General de la Temeridad y Malicia (mala fe) procesales», muy por el contrario, lo que nos mueve es que únicamente sea apreciada como sólo una herramienta de consulta; empero, más aún nos motiva el hecho de llamar a la reflexión (por ende a la actuación madura y razonada, en consecuencia) sobre estos temas/problema como son la temeridad y la malicia (mala fe) procesales que conllevan al abuso del derecho en perjuicio del sujeto procesal pasivo tanto como a la naturaleza del derecho. Con el sólo hecho que el presente trabajo sea eventualmente considerado (puesto sobre el tapete de cualquier palestra académica), debatido, analizado, reflexionado y criticado, nos daremos amplia y complacidamente por servidos.

\section{Sugerencias}

Dado que la creciente incidencia de la temeridad y malicia mala fe) procesales peruana son básicamente producto de la crisis de valores que nos agobia y que hace mucho hace agua por todos lados; sugerimos la inmediata implantación de una decidida, efectiva y sostenida política de Estado de inculcado de valores en la educación inicial y primaria principalmente, porque por psicología se tiene conocimiento que el ser humano asimila, aprende y fija los valores hasta la edad de doce años. Luego de esa edad, desde el punto psicológico (reiteramos), es prácticamente insulso modificar, en este caso, para mejor el aspecto axiológico de cada persona.

Proponemos el urgente desarrollo (por parte del Tribunal Constitucional peruano) de los supuestos y significados de la mala fe (malicia) y temeridad procesales, así como sus respectivos deslindes de los siete incisos del artículo II2 del Código Procesal Civil peruano. Desarrollo y 
deslindes que contribuirán en gran medida a la correcta determinación (de la existencia y efectos), y sanción de dichas prácticas procesales negativas. Además, incluir en dicho artículo el término malicia como sinónimo de mala fe, por ser más técnico legislativamente.

En tal sentido sugerimos, que para efectos del respectivo desarrollo y deslinde legislativo, así como de aplicación de políticas de Estado destinadas a conseguir el aminoramiento de su incorrecto accionar, reiteramos, que es imprescindible que los mismos no sólo deben estar orientados al nivel o dimensión procesal jurisdiccional, sino también, en los niveles procesal administrativo, como procesal corporativo particular.

Proponemos la urgente e insoslayable creación e implantación de un Registro Nacional e Internacional Integrado Judicial y Extrajudicial (Militar, Arbitral y Administrativo, entre otros) de Temerarios y Maliciarios Procesales el cual contenga el archivo unificado de los sujetos procesales que incurrieron en temeridad y/o malicia (mala fe) procesales, debiendo a la vez permitir las búsquedas por nombre de la persona, proceso, vía procesal y por número de expediente, para lo cual se deberá diseñar un programa informático especial creado en un gestor de base de datos; debiendo ser accesible a la población en general vía Internet. Consideramos que la creación de dicho registro contribuirá decididamente a la disminución paulatina de dichas prácticas tan perjudiciales para el derecho como para la sociedad.

Creemos que es inadecuado exigir que la actitud maliciosa o de mala fe (la misma que a nuestro entender se refiere el inciso 6 del artículo 112 del Código Procesal Civil peruano) tenga que ser «reiterada»; en primer lugar, porque la naturaleza misma de dicha práctica procesal negativa revela maldad (malicia), es decir, mayor gravedad que la temeridad; y en segundo lugar, porque inexplicablemente y de manera desproporcionada solo se exige (tal reiteración) a la malicia regulada en dicho inciso, pero sin embargo no ocurre lo mismo en ningún otro inciso del citado artículo.

Consideramos que las denominaciones más apropiadas (en lugar del abuso del derecho) son: «abuso del proceso», «abuso en el proceso» o «abuso de los derechos procesales», dado que, si bien es cierto, que lo se persigue es modificar, prolongar o postergar -sacando ventaja de manera ilegitima- la sentencia o sus efectos; para tal fin se hace uso abusivo de inconductas a nivel procesal; ergo, se abusa específica e inicialmente del o en el proceso.

\section{Propuesta legislativa}

Finalmente, luego de haber desarrollado los temas de la malicia (mala fe) y temeridad procesales, haber esbozado las respectivas conclusiones y sugerencias -utilizando las consideraciones y precisiones conceptuales de la presente investigación anteriormente expuestas (en el epígrafe: «el artículo 112 ('no deslindado') del Código Procesal Civil peruano», del presente trabajo)-, procedemos a formular la propuesta legislativa.

Así, es necesario que el art. II2 del Código Procesal Civil peruano, (dado que solo se limita a indicar «se considera que ha existido temeridad o mala fe en los siguientes casos», sin determinar específicamente que incisos están referidos a la temeridad y cuales a la mala fe, además de tomar en consideración que temeridad y mala fe no son sinónimos, como sí lo son desde nuestro punto de vista- la mala fe respecto de la malicia procesal y finalmente aprovechar para suprimir el término «reiteradamente» del inciso 6 del artículo señalado), sea sustituido por el siguiente texto:

«Art. 112 del Código Procesal Civil peruano:

II2.I. Se considera que ha existido temeridad procesal en los siguientes casos: 
i) Inc.1. Cuando sea manifiesta la carencia de fundamento jurídico de la demanda, contestación o medio impugnatorio.

ii) Inc. 2. Cuando a sabiendas se aleguen hechos contrarios a la realidad.

iii) Inc. 3. Cuando se sustrae, mutile o inutilice alguna parte del expediente.

II2.2. Se considera que ha existido mala fe (malicia) procesal en los siguientes casos:

i) Inc. 4. Cuando se utilice el proceso o acto procesal para fines claramente ilegales o con propósitos dolosos o fraudulentos.

ii) Inc. 5. Cuando se obstruya la actuación de medios probatorios.

iii) Inc. 6. Cuando por cualquier medio se entorpezca el desarrollo normal del proceso;

iv) Inc.7. Cuando por razones injustificadas las partes no asisten a la audiencia generando dilación (Inciso agregado por el Artículo 2 de la L. $N^{\circ}$ 26635, en fecha 23-06-96)».

\section{Bibliografía}

ALSINA, H. (I96I): Tratado teórico práctico de derecho procesal civil y comercial (Tomo IV segunda parte), Buenos Aires: Ediar S. A. Editores.

BIDART CAMPOS, G. J. (I968): Derecho constitucional (Tomo I), Buenos Aires: Ediar.

BUSTAMANTE ALSINA, J. (I992): Teoría general de la responsabilidad civil, Buenos Aires: Abeledo- Perrot.

CABANELLAS, G. (1984): Diccionario Enciclopédico de Derecho Usual (Tomo VIII), Lima: Editorial Heliasta.

CAPITANT, H. (I986): Vocabulario Jurídico, Buenos Aires: Ediciones Depalma.

CHANAME ORBE, R. (2002): Diccionario jurídico moderno, Lima: Gráfica Horizonte.

CHIOVENDA, G. (2004): Condena en costas, Argentina: Valletta Ediciones.

CORNEJO, P. (2008): «Síganme los buenos. Ética de entrecasa: el fin casi nunca justifica los medios», Revista Somos del diario El Comercio II43.

COUTURE, E. J. (1983): Vocabulario Jurídico, Buenos Aires: Ediciones Depalma.

DEVIS ECHANDÍA, H. (I984): Teoría general del proceso, Buenos Aires: Editorial Universidad.

ESPINOZA ZEVALLOS, R. J. (2005): Los principios procesales específicos del Código Procesal Constitucional peruano (Art., III del T. P.), en el derecho procesal constitucional peruano, Lima: Editora Jurídica Grijley.

FERNANDEZ DE LEÓN, G. (I972): Diccionario jurídico, Buenos Aires: Ediciones Contabilidad Moderna.

GOZAÍNI, O. A. (I988): La conducta en el proceso, Buenos Aires: Librería Editora Platense S.R.L.

GUASP, J. (I998): Derecho procesal civil (Tomo primero), Madrid: Editorial Civitas.

INFANTES MANDUJANO, P. A. (2000): Diccionario jurídico, Lima: Ediciones legales S.A.C.

LOHMANN LUCA DE TENA, G. (2004): «Los yuppies, algunos abogados y el nuevo idioma», Legal Express 44.

MAURINO, A. L. (200I): Abuso del derecho en el proceso, Argentina: Editorial La Ley.

MESINAS MONTERO. F. (2006): «Día del abogado. ¿Motivo para celebrar?», Legal Express 63.

MORALES GODO, J. (2005): Instituciones de derecho procesal, Lima: Palestra Editores.

PAlACIO, L. E. y AlVARAdO VElloso, A. (1992): Código Procesal Civil y Comercial de la Nación (Tomo II), Santa Fe: Editorial. Rubinzal Culzoni.

PALÉS, M. (2002): Diccionario jurídico Espasa Lex, Madrid: Editorial Espasa Calpe.

RAMBALDO, J. A. (200I): «El abuso procesal», en J. W. Peyrano (director), Abuso procesal, Buenos Aires: Rubinzal Culzoni Editores, p. 227. 
RAMOS NÚÑEZ, C. (2007): La pluma y la ley. Abogados y jueces en la narrativa peruana, Lima: Fondo Editorial de la Pontificia Universidad Católica del Perú.

RIBÓ DURAND, L. (I987): Diccionario de Derecho, Barcelona: Bosch Casa Editorial S.A.

SAGÁSTEGUi URTEAGA, P. (2003): Exégesis y sistemática del Código Procesal Civil (Volumen I), Lima: Editora Jurídica Grijley.

TORRES MANRIQUE, F. J. (2005): «La enseñanza del derecho», Revista Jurídica del Perú 63.

TORRES MANRIQUE, J. I. (2006): «Hacia una política de formación, capacitación y especialización jurídica en el Perú», Revista Jurídica del Perú (Edición homenaje al Maestro Carlos Fernández Sessarego) 69.

- (2008): «Piero Calamandrei Pimpinelli: gran maestro y procesalista de la juridicidad mundial», Jurídica, Suplemento de análisis legal del diario oficial El Peruano i94, p. 08.

VALDIVIA CANO, J. C. (1998): La caja de herramientas (Introducción a la investigación jurídica), Arequipa-Perú: Impresiones Zenith.

VARGAS, A. L. (200I): «El ejercicio abusivo del proceso (criticismo y relativismo filosófico-científico vs. existencialismo y realismo legislativo, jurisprudencial y doctrinario)», en J. W. Peyrano (director), Abuso procesal, Buenos Aires: Rubinzal Culzoni Editores, p. 296-297.

VARSI ROSPIGLIOSI, E. (2006): «El juego limpio y la incertidumbre de nuestro derecho», Legal Express 67.

- (2008): Derecho Deportivo en el Perú, Lima: Fondo Editorial de la Universidad de Lima. 